This is the peer reviewed version of the following article: Gurnell, A.M., Corenblit, D., García de Jalón, D., González del Tánago, M., Grabowski, R.C., O'Hare, M.T., Szewczyk, M. 2015. A Conceptual Model of Vegetation-Hydrogeomorphology Interactions within River Corridors, early view; DOI: 10.1002/rra.2928, which has been published in final form at DOI: 10.1002/rra.2928. This article may be used for non-commercial purposes in accordance with Wiley Terms and Conditions for SelfArchiving.

\title{
A Conceptual Model of Vegetation-Hydrogeomorphology Interactions within River Corridors
}

A.M. Gurnell ${ }^{1}$, D. Corenblit², D. García de Jalón ${ }^{3}$, M. González del Tánago ${ }^{3}$, R.C. Grabowski ${ }^{4}$ M.T. $\mathrm{O}^{\prime} \mathrm{Hare}^{5}, \mathrm{M}$. Szewczyk ${ }^{6}$

1 School of Geography, Queen Mary University of London, Mile End Road, London, E1 4NS, UK.

2 Clermont Université, UBP, 4 rue Ledru, 63057 Clermont-Ferrand Cedex 1, France and CNRS, UMR 6042, GEOLAB - Laboratoire de géographie physique et environnementale, 63057 ClermontFerrand, France

3 E.T.S. Ingeniería de Montes, Forestal y del Medio Natural. Universidad Politécnica de Madrid, 28040, Madrid, Spain.

4 School of Energy, Environment and Agrifood, Cranfield University, Cranfield, Bedfordshire, MK43 OAL, UK.

5 Centre for Ecology and Hydrology, Bush Estate, Penicuik, Midlothian, EH26 0QB, UK.

6 Environmental Information Centre UNEP/GRID-Warsaw, Poland, and Faculty of Civil and Environmental Engineering, Warsaw University of Life Sciences (SGGW), Warsaw, Poland.

\section{ABSTRACT}

We propose a conceptual model of vegetation-hydrogeomorphology interactions and feedbacks within river corridors (i.e. river channels and their floodplains) that builds on previous similar hydrogeomorphologically-centred models by:

(i) incorporating hydromorphological constraints on river corridor vegetation from region to reach scales.

(ii) defining five dynamic river corridor zones within which different hydrogeomorphological processes are dominant so that plants and physical processes interact in different ways, and considering the potential distribution of these zones longitudinally from river headwaters to mouth, laterally across the river corridor, and in relation to different river planform styles.

(iii) considering the way in which vegetation-related landforms within each zone may reflect processes of self-organisation and the role of particular plant species as physical ecosystem engineers within the context of the dominant hydrogeomorphological processes.

(iv) focussing, in particular, upon a 'critical zone' at the leading edge of planthydrogeomorphological process interactions, that is located somewhere within the area of the river corridor perennially inundated by flowing water (zone 1) and the area that is frequently inundated and subject to both sediment erosion and deposition processes (zone 2). Within the critical zone some plant species strongly influence the position and character of the margin between the river channel and floodplain, affecting channel width, channel margin form and dynamics, and the transition from one river planform type to another.

(v) considering the vegetated pioneer landforms that develop within the critical zone and how their morphological impact needs to be scaled to the river size. 
The model is illustrated using three example reaches from rivers within different biogeographical zones of Europe, and its potential application in the context of river management and restoration / rehabilitation is discussed.

\section{KEYWORDS}

Hydrogeomorphology, Fluvial processes, Biogeomorphology, Riparian vegetation, Aquatic vegetation

\section{INTRODUCTION}

Rivers and their floodplains are one of the most biodiverse environments on Earth (Tockner and Stanford, 2002). Agriculture, housing, industry and other land uses constrain the natural functioning of these environments (e.g. Gregory et al., 2002; Chin, 2006; James and Marcus, 2006; Wohl, 2006; Braatne et al., 2007). At the same time, river management activities in relation to water resources development, power generation, and flood defence have changed on the hydrogeomorphological (i.e. hydrological and fluvial geomorphological) processes that build river channels and floodplains and also directly modify river channel form, mobility and capacity; floodplain form; and the connectivity between rivers and their floodplains (e.g. Nilsson and Svedmark, 2002; Rinaldi et al., 2005; Graf, 2006; Downs et al., 2013).

Within Europe, river and floodplain environments are under increasing and frequently severe pressure such that few naturally functioning rivers or floodplains remain (e.g. Surian and Rinaldi, 2003; Hohensinner et al., 2011; Comiti, 2012; Wyżga et al., 2012). These pressures and changes have been accompanied by the widespread loss and degradation of riparian forests and wetlands (Hughes and Rood, 2003; Hughes et al., 2012) at a time when research is demonstrating that vegetation combines with hydrogeomorphological processes of water flow and sediment mobilisation-transportdeposition to drive channel and floodplain form, complexity and dynamics (e.g. Corenblit et al., 2007, 2009; Collins et al., 2012; Osterkamp et al., 2012; Gurnell, 2014). The research presented in this paper was developed within a European context. It proposes a conceptual model of how vegetationhydrogeomorphology interactions would occur in different European biogeographical settings if human pressures were removed. In so doing, it provides conceptual insights into how such interactions may be recognised more generally in impacted situations, and how they may be relevant to the management and rehabilitation of rivers and floodplains.

The conceptual model of vegetation-hydrogeomorphology interactions proposed in this paper builds on research, commencing in the later decades of the $20^{\text {th }}$ century, which has been reviewed recently (Gurnell, 2014) and is summarized briefly here. Before 2000, many researchers recognized that riparian vegetation responded to hydrogeomorphological disturbances, resulting in distinct spatial patterns in vegetation composition and structure that were associated with river channel and floodplain landforms and their evolution (e.g. Hupp, 1983, 1986; Osterkamp 1998; Robertson and Augsburger, 1999). Researchers also identified the consequences of changes in hydrogeomorphological processes for riparian vegetation (e.g. Johnson, 1994; Rood and Mahoney, 1995; Stromberg and Patten, 1996, Merritt and Cooper, 2000). In addition, there was recognition of the impact of vegetation on fluvial processes, forms and dynamics in relation to river bank stabilization, aggradation and channel narrowing (e.g. Graf, 1978; Rowntree, 1991; Friedman et al., 1996), widening (e.g. Kondolf and Curry, 1986; Madej et al., 1994), channel migration (e.g. Nanson and Beach, 1977), and the development of particular vegetation-associated landforms (e.g. Page and Nanson, 1982; McKenney et al., 1995; Tooth and Nanson, 1999). Since 2000, numerous field (see reviews by Corenblit et al., 2007, 2009), flume (e.g. Jang and Shimizu, 2007; Tal and Paola, 2010; Perona et al., 2012, Bertoldi et al., 2015) and theoretical investigations (see reviews by Camporeale et al., 2013, Solari et al., 2015) have revealed the importance of vegetation for river morphodynamics.

One development since 2000 of particular relevance to the present paper, is the proposal of some conceptual models which explicitly centre on interactions and feedbacks between hydrogeomorphological processes and vegetation. The 'island development' model of Gurnell et al. (2001) conceptualized how large wood and uprooted riparian trees initiate small (pioneer) islands, which then enlarge and coalesce through a cycle of interactions between (a) vegetation-controlled island growth and floodplain construction, and (b) hydrogeomorphologically-controlled island and 
floodplain erosion. The more recent 'large wood cycle' concept (Collins et al., 2012) describes a similar cycle based entirely on large, dead wood, and illustrates how the entire character of a river and its floodplain can be transformed by human disruption of the natural wood cycle. The four phase 'fluvial biogeomorphic succession' model of Corenblit et al. (2007) generalises these landformfocused concepts and introduces a broader theoretical foundation to vegetation-hydrogeomorphology interactions. Phase 1 is a 'geomorphic phase' during which hydrogeomorphological processes dominate and riparian vegetation is removed and rejuvenated by large floods. Vegetation recruitment occurs during phase 2, the 'pioneer phase', and although hydrogeomorphological processes remain dominant, young plants start to influence local sediment retention as their canopy and root systems develop. Phase 3 is the 'biogeomorphic phase', which is characterized by strong interactions between hydrogeomorphological processes and the establishing vegetation. In this phase, enhanced sediment deposition around vegetation and root reinforcement of the deposited sediment leads to rapid vegetated landform development. Phase 4 is the 'ecologic phase', where the vegetated land surface, progressively aggraded and stabilized during phase 3 , becomes increasingly disconnected from fluvial disturbances. The model conceptualises a distinct cycle of change in river margins, which are reset to phase 1 by large flood events. All of these and similar models are complemented by the 'model of plant strategies in fluvial hydrosystems' (Bornette et al., 2008), which predicts plant strategies (and associated life history traits) in relation to direct and indirect effects of flood disturbances, particularly erosion and deposition processes.

Recent research also provides potential extensions to the above conceptual models of vegetationhydrogeomorphology interactions. First, founded on research on self-organisation within ecosystems (see review by Rietkerk et al., 2004), the process of pioneer island development, coalescence and destruction was placed within a conceptual framework of 'self organisation of river islands' by Francis et al. (2009). Second, the analysis of UK data sets at site to national scales, showed that emergent aquatic plants can also interact with hydrogeomorphological processes to drive a cycle of pioneer landform development and floodplain construction (e.g. Gurnell et al., 2013). Third, a new conceptual synthetic model of 'changing river channels' (Gurnell et al., 2012) was proposed for gravel-bed rivers in humid temperate environments, which (a) incorporates both riparian and aquatic vegetation, (b) identifies that particular plant species can act as physical ecosystem engineers (sensu Jones et al., 1994, 2010) driving pioneer landform development and cycles of river margin evolution, and facilitating colonisation by other plant species, and (c) proposes that the character and dynamics of the pioneer landforms and their associated river margins varies with river type (i.e. low sinuosity single thread, meandering, wandering, island-braided, bar-braided).

The 'conceptual model of vegetation-hydrogeomorphology interactions' proposed here, builds on these models in three main ways.

I. It defines five dynamic zones within river corridors, in which different hydrogeomorphological processes dominate so that plants and hydrogeomorphological processes interact in different ways. It considers how the five dynamic zones might be distributed across river corridors according to valley confinement and river type.

Therefore, the model extends beyond the margins of the river that were included in the previous conceptual models to incorporate the entire river corridor (i.e. the river and its entire floodplain). It also considers all relevant hydrological process in addition to the fluvial processes incorporated in previous conceptual models.

II. Building upon the previously-proposed concepts of pioneer landform development and self-organisation, the model implements these concepts within all five river corridor zones and incorporates the dominant hydrogeomorphological processes that are involved in each case.

III. Lastly, the model emphasises a 'critical zone' of plant - hydrogeomorphology interactions that exists within the area of the river corridor incorporated within zones 1 and 2 . This embeds previous concepts of plant-hydrogeomorphology interactions along river margins into the new five zone river corridor model. It also catalogues pioneer landform types that are dependent on interactions among hydrogeomorphological processes and wood, riparian trees, and aquatic plants within this critical zone.

This paper describes a conceptual model incorporating the above three elements ( $i$ to iii). The model is then applied to three European rivers that are near-natural in their current form and dynamics, are of different planform type and are located in different biogeographical regions of Europe. Finally, since 
the conceptual model represents forms and processes that have been found in association with nearnaturally-functioning European river corridors, the paper concludes with a section on the potential application of the model. This concluding section considers the potential for the model to be applied to river systems beyond Europe and also how the model could provide relevant information for the management and rehabilitation of human impacted river systems.

\section{A CONCEPTUAL MODEL OF VEGETATION-HYDROMORPHOLOGY INTERACTIONS WITHIN RIVER CORRIDORS}

This section develops and describes the conceptual model under five sub-headings. First it considers hydrogeomorphological constraints on river corridor vegetation from biogeographical region to reach scales, which moderate the potential vegetation that can participate in interactions with hydrogeomorphological processes. Second, the five dynamic zones of vegetationhydrogeomorphology interactions are defined along with their distribution across river corridors, along rivers from source to mouth, and in association with different river planform styles. Third interactions among plants and hydrogeomorphological processes are considered, building on the concepts of selforganisation and physical ecosystem engineering and considering how these might be observed within the five zones. A 'critical' zone is defined which encompasses the leading edge between vegetation encroachment and hydrogeomorphological disturbance, where interactions are particularly intense and drive the position, character and mobility of the river edge. This critical zone is located somewhere within zones 1 and 2. Fourth, landform development within the critical zone is discussed. The influence of plants on landform development within the critical zone, and thus the character of the resulting river margins, is scaled to the size of the river. Finally, the phenomena discussed in the preceding four sub-sections are synthesized diagrammatically.

\section{Hydrogeomorphological Constraints on River Corridor Vegetation}

The vegetation species and communities found in river corridors reflect three broad sets of hydrogeomorphological constraints: climate, moisture availability, and fluvial disturbance (e.g. Steiger et al., 2005; O'Dorico et al., 2010; Evette et al., 2012; Sponseller et al., 2013; McShane et al., 2015), which with rock type influence the potential species composition and vigour of vegetation that may be found at all spatial scales from biogeographical region to reach (Table 1), and thus place physical boundaries on potential vegetation - hydrogeomorphology interactions. Furthermore, planthydrogeomorphology interactions depend on the presence of plants possessing traits that enable them to tolerate or avoid the hydrogeomorphological disturbances to which they are subjected (see reviews by Bornette et al., 2008, Gurnell, 2014).

At the catchment scale, the climate of the biogeographical region in which the catchment is located and longitudinal climatic gradients along the river system from headwaters to mouth are fundamental influences on the 'potential' composition of river corridor vegetation. These constrain the plant species and communities that may be present, especially in areas that are remote from the river channel (e.g. Polce et al., 2011), and particularly in an arid climate setting.

As the impact of climate cascades from the catchment through landscape units to river segments and reaches, the 'effective' precipitation regime is translated into surface water, soil moisture and groundwater, further controlling the plant species that are present. The river flow regime dictates the reliability of flow within the river network and thus the availability of moisture to the river channel and its margins through the year. Moisture availability is further moderated at segment and reach scales by drainage from adjacent hillslopes and the permeability of the river bed and margins, and thus moisture dynamics within and through alluvial soils and sediments, including flow within alluvial or deeper aquifers (groundwater - surface water interactions) and direct surface and subsurface drainage from surrounding hillslopes (e.g. Booth and Loheide, 2011; Cunningham et al., 2011; Kath et al., 2014).

Lastly, fluvial disturbances, including depth and duration of inundation, shear stresses or drag imposed on plants by river flows, and sediment erosion (uprooting) and deposition (burial) place further constraints on the plant species that are present. These disturbances reflect the catchment water balance, the runoff and sediment supply regimes to the river network at the landscape unit 
scale, and the resulting river flow and sediment erosion-transport-deposition regimes, which are moderated at the segment to reach scale by the valley-channel gradient, valley width and topography, and river channel style and size (Table 1). The river's flow regime and flow extremes strongly affect the structure and development of riparian plant communities throughout the catchment's river network (e.g. Pettit et al., 2001; Stromberg, 2001; Nilsson and Svedmark, 2002; Lytle and Merritt, 2004; Rood et al., 2003, 2005, García-Arias et al., 2013). This influence is both direct and indirect, through a cascade of flow-related hydrogeomorphological processes including sediment erosion, transport and deposition, in addition to moisture availability that is related to soil and groundwater hydrological conditions. Aquatic plants also respond strongly to hydrogeomorphological controls (e.g. Riis and Biggs, 2003; Baattrup-Pedersen et al., 2006; Daniel et al., 2006), particularly flow depths, velocities, sediment dynamics and bed sediment properties.

\section{Five Dynamic Zones of Vegetation-Hydrogeomorphology Interactions}

The above-described hydrogeomorphological constraints determine the potential range of species that may be present along river corridors. Within river corridors, hydrogeomorphological constraints vary spatially as well as temporally, giving rise to zones within river corridors where particular subsets of processes dominate.

Although moisture availability within a river corridor may be highly spatially variable, there is usually an underlying vertical pattern in moisture availability that depends on depth to the water table, and an underlying lateral pattern that reflects hydrological linkages between hillslopes, river corridor and river channel. Strong lateral disturbances are attributable to the frequency of inundation, associated flow velocities and surface shear stresses, and the mobilization, transport and deposition of sediments. These lateral disturbances change continually through time as river discharge varies and water spreads from the river channel into the river corridor. As a result, a lateral gradient in plant species and vigour should be expected at the reach scale, which may vary longitudinally from river headwaters to mouth. This is expressed in the model of plant strategies proposed by Bornette et al. (2008), which considers the distribution of traits along the longitudinal and transverse gradients of hydrogeomorphological connectivity of temperate rivers. Indeed, the above-described longitudinal, lateral, and vertical process gradients, their temporal variability and ecological consequences have long been recognized (Ward et al., 2002). The conceptual model synthesises these gradients into five dynamic lateral zones within river corridors, each dominated by different hydrogeomorphological processes and displaying a temporally dynamic lateral extent that also varies from river headwaters to mouth and with river type. These zones reflect the well-understood hydrological and fluvial processes introduced in the preceding section and described fully in numerous texts (e.g. Charlton, 2008, Hendriks, 2010; Uhlenbrook, 2011; Wohl, 2013, Kondolf and Piégay, 2016) and the 'multiple ecological roles of water in river networks' reviewed by Sponseller et al. (2013). However the zonal concept that is associated with vegetation - hydrogeomorphological interactions is new and central to the conceptual model.

Figure $1 \mathrm{~A}$ illustrates schematically how five different lateral zones, dominated by different hydrogeomorphological processes, may exist within a river corridor, and Figure $1 \mathrm{~B}$ illustrates how their distribution may vary longitudinally from steep, confined headwaters to lower gradient, unconfined floodplain reaches. Note that the zones are separated by transitions in Figure 1A, representing both their fuzzy (transitional) margins and their temporal variability in response to sequences of hydrogeomorphological events and vegetation encroachment. To retain clarity, such transitions are not represented in subsequent Figures, but it is crucial to remember that they exist in space and are dynamic, along with the spatial extent of the zones, through time.

In moist environments, a zone of perennially-flowing water is present within the channel (zone 1, Figure 1). This continuously inundated zone has the deepest water, highest flow velocities and shear stresses at all flow stages, making it the most heavily disturbed zone with the highest potential for sediment dynamics, presenting a very hostile environment for plants. Beyond zone 1, the frequency, duration and depth of inundation all generally decrease towards the outer limits of the river corridor, although interrupted locally by small variations in land surface elevation. Thus Zone 1 transitions into Zone 2, which supports the most frequent, deep, and prolonged inundations, and highest flow velocities and shear stresses of the periodically-inundated zones (2, 3 and 4). High shear stresses and flow velocities promote sediment mobilization and erosion during high flow stages, and thus the 
highest potential for plants to be damaged, uprooted or buried. With increasing distance from or elevation above the river, inundation depth, duration and frequency generally decrease, reducing the potential for sediment erosion and mobilization, and leading to a progressive fining of transported and deposited sediment across zone 3 until, in zone 4, sediment dynamics are negligible during inundation apart from the flotation of organic material. In zone 5 , which includes the most elevated areas of the river corridor and those that are most remote from the main river channel, inundation is extremely rare. Here, subsurface water dynamics and rainfall-driven overland flow become the dominant hydrogeomorphological controls on vegetation.

The relative extent of the zones varies from river headwaters to mouth (Figure 1B). For simplicity, in Figure 1B, zones 2 to 4 are shown to gradually widen downstream and then narrow slightly towards the river mouth as fining sediments become more cohesive and erosion-resistant. This enormous simplification represents the fact that both unit stream power and bed and bank material size tend to decrease. Therefore, all 5 zones should persist but their size is likely to vary with local conditions, including: sediment cohesion (resistance to erosion); valley confinement (concentration of flow energy and groundwater); and river planform type (Figure 2). Figure 2 sketches indicative proportions of an unconfined river corridor that might be attributable to zones 1 to 5 according to 7 river planform types. In some cases, adjustments in vegetation-hydrogeomorphology interactions may not only result in spatio-temporal shifts in the extent of the zones but also a change in the river planform type (e.g. Griffin and Smith, 2004; Collins et al., 2012).

The biogeomorphic character of all zones is likely to vary across different biogeographical regions, with the greatest contrasts being evident in zone 5 . In moist climates, high moisture availability in zone 5 would be expected to support a dense vegetation cover, whereas in dry climates, this zone may suffer from very low water availability and thus a very sparse and patchy vegetation cover (Sponseller et al., 2013). In the latter case, the densest and most vigorous vegetation would be expected in zones 3 and 4 , which, during periods with low precipitation, would benefit from lateral seepage from the river or, in ephemeral systems, from groundwater in the alluvial sediments below the river bed. However, complex responses and high zonal dynamics should be expected in response to changing combinations of moisture availability and disturbance regimes in drylands (Stromberg et al., 2007, 2010).

Within real river systems, rather than the greatly-simplified schematic of Figure 1, these longitudinal and lateral zones are spatially far more irregular and patchy than the schematic simplifications of Figure 1 and 2, and transitions between zones are fuzzy. Furthermore, the hydrogeomorphological processes within the zones vary greatly through time, although the zones remain differentiated by the processes that dominate in aggregate. The transitions between zones also move through time in response to short (one or a succession of floods), 'historical' ( $10^{2}$ years) and long term ( $>10^{3}$ years) temporal shifts in hydrogeomorphological processes and their aggregate behavior. Where a river is confined or partly confined by its valley, some of the outer zones may be missing.

Finally, in the preceding discussion, the hydrogeomorphological limits on the zones has been presented deliberately in an entirely descriptive way. While it is tempting to place process-based quantitative limits on these zones, this must be done with extreme caution until they have been widely determined in the field, since they are likely to vary greatly, particularly between biogeographical regions and river types. Nevertheless, researchers have previously related plant species patterns in river corridors to processes such as inundation duration and flood frequency (see review by Osterkamp and Hupp, 2010). Based on an a analysis of data for the Tagliamento River, Italy (Bertoldi et al., 2009), indicative values for the broad limits to the zones within a temperate climate setting might be: zone 1 - time inundated $>90 \%$; zone 2 - flooded more than once in $\sim 2$ years; zone $3-$ flooded more than once in $\sim 5$ years; zone 4 - flooded more than once in $\sim 50$ years; zone 5 extremely rarely flooded (less than once in 50 years).

\section{Interactions between Plants and Hydrogeomorphological Processes within the Five Zones.}

The preceding section has described five dynamic zones within river corridors that are dominated by different hydrogeomorphological processes. In this section, interactions between these dominant processes and vegetation are considered. These interactions may fluctuate in quality and intensity through time according to the intensity of the hydrogeomorphological processes and the ability of the vegetation to survive the disturbances and to recolonise areas where vegetation has died from 
hydrological stresses or has been eroded and removed or buried. However, the interactions give rise to characteristic landforms and landform assemblages (e.g. Table 2).

The development of characteristic assemblages of vegetation-related landforms within the zones of the river corridor can result from processes of self-organisation under the local hydrogeomorphological regime. These develop because local interactions and feedbacks among organisms (plants) and the environmental (hydrogeomorphological) processes occur even where the background environmental conditions are not heterogeneous (Scheffer et al., 2005; Rietkerk et al., 2004; Rietkerk and van de Koppel, 2008, Table 2). For example, feedbacks occur between water availability and plant growth in dryland environments that are relevant to zone 5 and potentially also zones 4 and 3 (Rietkerk et al., 2000). In such dry environments, vegetation shades the ground reducing surface evaporation, and root systems encourage water infiltration, enhancing local water availability such that vegetation persists once it is present but once vegetation disappears the bare soil is too hostile for plant colonisation. Similarly in waterlogged wetland (e.g. peatland) ecosystems, there is a feedback between groundwater depth and plant productivity, such that patches of highly productive plants tend to be present on locally elevated, and thus relatively drier, sites (e.g. Wetzel et al., 2005). In both arid and wetland examples, the patches of plants harvest resources (water, nutrients) from their surroundings. As resource availability decreases, vegetation goes through a sequence of increasing patchiness until it disappears and bare soil or a different vegetation type replaces it. Greater inputs of resources are required to reverse this process. Vegetated patches, often focussed on shrubs with surrounding bare areas, are the outcome of these processes in drylands, whereas vegetated tussocks or hummocks of organic material evolve in peatlands.

In fluvially-disturbed systems, self-organisation processes are accentuated by interactions between plants, the land surface and flowing water and sediment (Francis et al., 2009, D'Odorico et al., 2012, Corenblit et al., 2015) giving rise to questions regarding the degree to which patterns emerge or are imposed by physical conditions or processes and other ecological factors (Scheffer et al., 2013). In general, local vegetated areas with relatively high above-ground biomass (e.g. vegetated patches in semi-arid areas; vegetation hummocks / tussocks and ridges in wetlands; pioneer islands on river bars; macrophyte stands on river beds) slow flow velocities during inundation and trap transported sediments, organic matter and plant propagules. Constriction of flowing water between elevated patches increases inter-patch flow velocities so that less sediment, organic matter and propagules are deposited. Where flow velocities are sufficiently high, these areas may even be scoured. In addition, when rainfall or overland flow occur in dryland areas, vegetated patches preferentially intercept and absorb water (e.g. Wainwright et al., 2002). In zones 1 and 2, hydrogeomorphology - vegetation interactions become particularly marked. Bare areas colonised by plants may develop into larger vegetated patches, become elevated by sediment trapping and root reinforcement to form pioneer landforms that may eventually coalesce into larger landforms (Gurnell et al., 2001). At the same time these pioneer landforms also constrain and concentrate water flows in certain locations during inundation of the fluvial corridor, maintaining bare areas and retarding coalescence.

The morphological patterns and pioneer landforms that develop under processes of self-organization are usually initiated by particular plant species that act as 'ecosystem engineers' (Jones et al., 1994, 2010). These species control key characteristics of the ecosystem by modifying the properties of their environment and, in so doing, creating new environmental conditions that can support other species. By altering their environment these species are actively involved in 'niche construction' (Odling-Smee et al., 1996), increasing their chances of survival and reproduction. Such plant species may interact with hydrogeomorphological processes such as moisture supply (soil moisture and permeability, groundwater, overland flow from precipitation and/or river inundation) in zones 3 to 5 and may trap fine sediments (from overland flow in zone 5 and also from inundation in zones 3 and 4) to improve moisture retention capacity and engineer floodplain habitats. These interactions affect the vegetation cover (species, communities, age and patch structure) and micromorphology of the land surface of zones 3 to 5 . However, a 'critical zone' for physical ecosystem engineering of fluvial systems by plants exists within the area of the river corridor that is perennially inundated by flowing water (zone 1) and adjacent areas that are frequently inundated and subject to significant shear stresses and erosion and deposition of sediment (zone 2). Somewhere within zones 1 and 2 is the leading edge of planthydrogeomorphological process interactions. Here some plant species actively influence the position and character of the margin between the river channel and the floodplain and so affect channel width, channel form, channel margin dynamics and the transition from one river planform type to another. 
These 'engineer' species vary with climate, moisture availability, fluvial disturbances and river type and they show particular traits that enable them to survive and promote pioneer landform

development (see Gurnell, 2014 for a recent review) within the different zones.

\section{Pioneer Landform Construction in the Critical Zone}

This section specifically focuses on landform construction in the critical zone within zones 1 and 2 , since this is the zone in which the position, dynamics and morphology of the margin between the river and its floodplain is determined.

Within the critical zone of fluvial ecosystem engineering by plants, areas exhibiting self-organised patchiness are dynamic in time and space. As either vegetation or hydrogeomorphological processes come to dominate, there is a transition from patchy vegetation assemblages to either bare sediment (vegetation removed by fluvial disturbances) or a more homogenous, continuous vegetation cover, as represented by the 'fluvial biogeomorphic succession' of Corenblit et al. (2007, 2009). Furthermore, between these end points the patches either become smaller and more widely spaced (under fluvial disturbances) or enlarge and coalesce (under vegetation expansion and succession). Transitions across river corridors from more disturbed to less disturbed zones show a gradient from bare sediment through patchy vegetation to a more continuous vegetation cover in zones 1 to 3 , and transitions between river types through time show a similar gradient or its reverse.

In many ways, plants can be considered to be analogous to sediment particles or aggregates of particles within this critical zone in relation to their interactions with hydrogeomorphological processes (Gurnell, 2007). The larger and denser the plant-related 'particle', the higher the shear stresses and flow velocities required for mobilisation and transport. However, plants root into the substrate, making them more difficult to mobilise than mineral particles, and allowing them to act as 'obstacle clasts' (sensu Brayshaw et al., 1983) that induce upstream and downstream accumulations of other plant and sediment particles, so initiating the development of 'pioneer landforms'. Plant morphology is also more complex and plastic over the short (reconfiguration during floods; phenotypic reactions related to flood regime) and longer term (genotypic adaptation) than mineral sediment particles, with an increased potential to snag against the river channel boundary and be deposited. These properties allow plants to be more easily retained in river systems than sediment particles, and thus to act as important stabilisation and retention structures for other plant and mineral sediment particles. These fundamental differences between mineral particles and plants have allowed the latter to shape river morphology and related gradients over an evolutionary time scale (Corenblit et al. 2015).

Once mobilised, large and irregularly shaped plants or plant pieces (large wood pieces, uprooted trees and aquatic plants) can become jammed in 'small' channels, providing major features that can transform flow hydraulics and retention and sorting of sediment particles, creating large landforms through scour and deposition processes, when scaled to the river size. Equally, plants that are 'large' relative to the size of the river channel (or channels in multi-thread systems) can dominate flow hydraulics, sediment dynamics and channel form. Here 'small' and 'large' are relative terms, comparing the size of the vegetative particles to the size of the river channels and flow paths through which they are transported. In addition, for living plants, there is an upper threshold of flow velocity or shear stress that limits their ability to persist in a particular location (e.g. the thresholds of stream power for pioneer landform construction by emergent aquatic plants identified by Gurnell et al., 2010, 2013). These examples illustrate why it is important to consider scaling between plant size and the size of river with which they interact.

Church (1992) defined three size classes of river ('small', 'intermediate', 'large') according to relative roughness (D/d): the ratio of grain diameter of the bed material (D) to flow depth (d). He suggested 'small' rivers have $D / d>1$; 'intermediate' rivers, $1>D / d>0.1$; and 'large' rivers, $D / d<0.1$. These separate rivers where individual particles, single aggregations of particles, or neither of these have a major influence on channel form. Church (1992) also considered the influence of large wood on rivers, considering that individual wood pieces would be significant morphological elements in 'small' rivers, whereas aggregations of wood pieces (wood jams) could block rivers of 'intermediate' size. Gurnell et al. (2002) extended this concept by comparing the size of large wood pieces to the size of the river channels through which they are transported, suggesting that 'small' rivers have channel width < median wood piece length; 'intermediate' channels have channel width < upper quartile wood piece 
length; and 'large' channels have widths greater than the length of all the wood pieces delivered to them. Extending these scaling approaches to living plants, individual plants could form a significant component of 'small' rivers, single stands of plants could form a significant component of 'intermediate' rivers, and assemblages of plant stands could be a significant component of 'large' rivers in terms of the creation of pioneer to larger landforms. Thus, the size of pioneer vegetated landforms initiated within the critical zone, the nature and size of the vegetation features initiating the landforms, and the number and density of pioneer landforms that evolve within the critical zone, is scaled to the river size.

Table 3 synthesises evidence from the literature on the types of pioneer landforms that are initiated by trees, shrubs, large wood and tree seedlings within the critical zone of rivers of different size. Table 4 describes pioneer landforms associated with aquatic plants within the critical zone, which reflect a temporal sequence of fine sediment trapping, reinforcement and aggradation. Three types of aquatic plant-related feature can develop: (i) low amplitude mounds around plants and below the low-flow water level; (ii) moderate amplitude mounds that extend vertically to the low-flow water level and (iii) large amplitude mounds that emerge above the low-flow water level and eventually aggrade to the level of the surrounding floodplain. The three feature types represent landform development stages, initiated within zone 1 , and are distinguished by the plant species that they support. In very low energy anastomosing systems, these may develop further into low levées along anabranch margins within zone 3 (Table 4). Because most aquatic plants are adversely affected by riparian shading, landform building is confined to channels where shading is low. However, within the environment of low energy, narrow, unshaded channels, interactions between aquatic plants and fluvial processes are fundamental to channel form and channel dynamics (for recent reviews see Gurnell et al., 2012, Gurnell, 2014).

\section{Linking Physical Processes, Vegetation, Zones and Pioneer Landforms}

To illustrate some of the above-described phenomena and the linkages between them, Figure 3 shows a schematic cross profile from the centre of a river to the outer edge of the floodplain in a moist environment where there is negligible moisture stress on the floodplain. It illustrates water table and river levels under wet season, dry season and average conditions (Figure $3 \mathrm{~A}$ ), indicative of moisture availability to plants, against the 5 corridor zones as they might extend around a river of medium flow energy. Figures $3 \mathrm{~B}, 3 \mathrm{C}$ and $3 \mathrm{D}$ illustrate the aggregate lateral distribution of fluvial disturbance intensity (B), vegetation cover and biomass (C), and plant-hydrogeomorphological process interaction intensity within the critical zone (D) in the context of high, medium and low energy flow regimes. Since the graphs all represent aggregate conditions over time, fuzziness due to transitions and temporal variability are not illustrated. Even so, Zones 1 to 4 would be expected to shift to the right in a low energy river environment and to the left in a high energy river environment. In a low energy river environment, vegetation cover and biomass often extend into the perennially inundated channel (Figure $3 \mathrm{C}$ ), and thus the plant species within the critical zone (Figure 3D) are aquatic, particularly emergent, species. As river energy increases, the critical zone shifts from the channel towards the margins because shear stresses are too high for the survival of a significant aquatic plant cover. Under these circumstances riparian plants, particularly trees and shrubs, dominate the critical zone and interact with hydrogeomorphological processes. In either case, certain (aquatic or riparian) plant species act as physical ecosystem engineers, constructing pioneer landforms at the leading edge of the vegetated areas of zones 1 and 2, and thus determining the precise position and form of the river channel margins.

\section{THREE EXAMPLE APPLICATIONS OF THE CONCEPTUAL MODEL}

\section{Three example river reaches}

The conceptual model is now briefly illustrated with reference to reaches of three example rivers (River Tagliamento, Italy; River Guadalupejo, Spain; River Narew, Poland). These river reaches retain near-natural interactions between vegetation and hydrogeomorphological processes in very different environmental settings (Table 5). They are drawn from three contrasting European biogeographical regions (Alpine, Mediterranean-West Iberian, Central European) and subregions (Eastern Alpine, Luso-Extremadurense, Hemiboreal Baltic), and so are subject to different climatic conditions and 
native vegetation. They also exhibit different hydrogeomorphological process regimes, showing differences in flow regime type and channel slope, and thus flow energy; valley confinement; bed material calibre; and groundwater-surface water interactions (Table 5). They also illustrate pioneer landform development in the critical zone driven by different engineer plant species. Based upon the dominant ecosystem engineer plant species (Table 5) the three rivers could all be described as 'large' in relation to the trees and wood (Tagliamento), Flueggea tinctorea shrubs (Guadalupejo) and aquatic plants (Narew) that influence landform development.

The strong contrasts in both vegetation and hydrogeomorphological processes across the three example sites, results in different river planforms and other morphological characteristics (Table 5) and different spatio-temporal distributions of the river corridor zones (Figure 4). It should be stressed once more, that the margins between zones are fuzzy and so the lines marking their limits in Figure 4 are only indicative and relate to the date when the air photograph was captured. Furthermore, as a result of the complex micro-topography of these near naturally functioning corridors, the aggregate limits of these zones during any particular time period may reflect vertical as well as lateral gradients in hydrogeomorphological processes.

\section{Tagliamento River, Italy}

The partly confined reach of the gravel-bed Tagliamento River, Italy is subject to a moist, temperate climate, and functions according to the high energy schematic of Figure 3 . In the selected reach, the river has a well-developed floodplain on its right bank but is tightly confined on the left bank (Figure 4A). It is a perennially-flowing, braided to high-energy anabranching reach according to the temporal sequence of interactions between vegetation and fluvial processes in the critical zone. The photograph in Figure 4A was taken after a very large flood in 2000 and another large event in 2004. As a result, the established islands, which are predominantly subject to surface aggradation and so represent a part of zone 3 , were relatively small in area at that time.

Zones 1 and 2 are not differentiated in Figure 4A, although the flowing braid channels in the photograph are indicative of the typical extent of zone 1 . The widespread patches of vegetation across the exposed braid bars (zone 2) are pioneer islands (Edwards et al., 1999; Gurnell et al., 2001), developing around deposited, sprouting riparian trees (Populus nigra and Salix spp.), that were uprooted by the 2000 and 2004 floods. These deposited trees are acting as physical ecosystem engineers within the critical zone of vegetation-fluvial process interactions, trapping fine sediment to form pioneer island features that can be colonised by other plant species. The numerous vegetated pioneer islands interact with hydrogeomorphological processes, enlarging and coalescing to form larger islands and extending over a larger area during periods when extreme floods are rare, or shrinking, splitting and being removed by erosion during periods dominated by extreme floods. These interactions drive a complex mosaic of dynamic patches that, in addition to islands, include wood jams, scour ponds, and areas of different sediment calibre. The pioneer vegetated landforms present include all of the large river allochthonous jams, living wood and seedling features listed in Table 3 with the exception of meander jams and counterpoint jams and scrolls.

Zones 3 and 4 are also not differentiated in Figure 4A because this area of the river corridor has a complex topography inherited from island coalescence and floodplain development in the past, which is reflected in the complex structure of the vegetation. In particular, a network of intermittent side channels represent zone 3 as they are subject to inundation and sediment deposition during floods which is progressively filling them to the level of zone 4 . These zone 3 channels show a series of vegetation-related features including wood jams and semi-permanent ponds retained by wood or sediment, that are often colonised by aquatic plants that further aid sedimentation and terrestrialisation. The higher areas of this part of the river corridor are only occasionally inundated and so aggradation is small to negligible (zone 4), whereas the largest and deepest side channels in this area continue to be subject to erosion and so form local extensions of zone 2 during large flood events, or even zone 1 if they retain perennial flow. In these side channels some of the small and intermediate river in situ and combination jams are found (Table 3), including bank input jams, log steps, flow deflection and channel spanning jams. 
Finally zone 5 is an area that is flooded extremely rarely, so the vegetation here contains many terrestrial species that benefit from plentiful soil moisture provided by drainage from adjacent mountain slopes and from elevated groundwater levels.

\section{Guadalupejo River, Spain.}

The lower reaches of the Guadalupejo River, Spain are affected by a hot, dry mediterranean climate. Low soil moisture availability strongly constrains the vegetation, and the river flows through a neardryland landscape. A schematic representation of the distribution of moisture, fluvial disturbance intensity, vegetation cover and biomass, and the critical zone of vegetation-hydrogeomorphology interactions in the context of dry climate perennial and ephemeral rivers of different energy is presented Figure 5. In Figure 5, the lateral distribution of the five zones approximates that of a medium energy river.

The Guadalupejo River is a high energy, flashy, partly-confined system, where river flows are intermittent, representing a transition between the perennial and ephemeral situations illustrated in the schematic diagrams of Figure 5. The example reach (Figure 4B) is located in the lower reaches of the river. In this reach, zone 1 is restricted to occasional pools in the channel bed, so that virtually the entire channel and its edges form part of zone 2, with small elevated areas within the channel representing zone 3 (Figure 4B), and the critical zone of interactions between vegetation and hydrogeomorphological processes extends across most of the river channel bed and banks. As a result of the relatively sparse woody vegetation within the river corridor, there are few wood and treerelated pioneer features. Occasional bank input jams, log steps, flow deflection jams and pioneer islands (Table 3) are all observed in the main and side channels. However, the dominant engineer plant within the critical zone is the riparian shrub, Flueggea tinctorea, which colonises exposed bar surfaces, where it traps finer sediment to form small island patches that aggrade, coalesce and facilitate colonisation by other plant species. Flueggea tinctorea plays a major role in initiating zone 3 island patches and marginal benches within the river channel. As the latter aggrade, they form extensions to the floodplain along the channel margins.

The floodplain pockets along this partly-confined river fall entirely into zones 3 and 4 . Here, the dry summer conditions lead to an open parkland type of vegetation, with widely spaced trees. Grazing further reduces vegetation biomass and exposes soils, resulting in high fine sediment dynamics that extend zone 3 at the expense of zone 4 . Within this narrow river corridor, zone 5 is rarely present and is confined to occasional, low terraces. Thus most of the floodplain is within zone 3 , with widelyspaced trees and shrubs, and sparse grasses competing for water in the dry summer and so forming a characteristic self-organised patchy vegetation pattern that is further enhanced by sediment mobilisation and trapping during flood events. Some closely-spaced trees, including woodland patches, occur in the lowest areas of the floodplain and often form bands along main and side channel margins where they have access to sub-surface water. Their root systems reinforce the river banks, and their canopies retain sediment to build the river bank line.

\section{River Narew, Poland}

The unconfined reach of the Narew River within the Narew National Park is a low energy, anabranching (anastomosing) system, subject to a cool climate, where evaporation is low and moisture is readily retained within the river valley. A schematic representation of the distribution of available moisture, fluvial disturbance intensity, vegetation cover and biomass, and the critical zone of vegetation-hydrogeomorphology interactions in this environmental context is presented in Figure 6.

The Narew anabranches have peat or sand beds, peat banks, and extremely low gradients $(\sim 0.0002$, Klimaszewski, 1981; Gradziński, 2004), which support the perennial presence of flowing water even at the lowest discharges, low flow velocities, and weak rates of drainage from the floodplain to the river. Peat development and the wetland vegetation of the floodplain depend entirely upon maintenance of a high water table by reliable river flows (Banaszuk, 1996). The pattern and dynamics of the complex mosaic of wetland plant communities within this reach are determined by hydrological processes including the duration of flooding; the rate of movement of groundwater; and the proximity of the water table to the ground surface. 
The entire river corridor is subject to continuous near-surface water tables and, although marked as zones 4 and 5 in Figure 4C, most of the corridor falls within zone 4, with zone 5 confined to small elevated areas and the outer edges of the valley bottom. Throughout zones 4 and 5 , tight interactions between vegetation and hydrological processes drive peat formation. In many areas, interactions between plants and hydrological processes lead to a self-organised, tussocked microtopography and a complex vegetation pattern.

Two-way interactions between vegetation and a full set of hydrogeomorphological processes are confined to the permanently inundated anabranching channels and their margins, and the plants that act as physical ecosystem engineers are aquatic macrophytes. There is no zone 2 , since fluvial erosion of the sand bed is limited to the permanently inundated zone. Zones 1 and 3 are confined to the areas occupied by or immediately adjacent to the anabranch channels. Within zone 1 , the formation of geomorphic features on the river's peat and sand bed and margins depends upon the stabilising influence of vegetation. Plants are crucial to river morphodynamics: they provide the peat material from which the floodplain and channel banks are constructed; reinforce these organic river banks; encroach into and narrow the anabranch channels; colonize the channel bed; and induce local channel shallowing (Gradzinski et al., 2003). Submerged, floating-leaved, and emergent aquatic plants (e.g. Sagittaria sagittifolia and Nuphar lutea) colonise river channel beds, whereas emergent species (e.g. Phragmites australis) colonise the banks. Colonisation, stabilisation and aggradation of river channel bed and margins by wetland and aquatic plants, notably Phragmites australis, contribute to bar formation, which is the main process by which vegetation influences evolution of this low energy system, including channel narrowing and avulsion (Gradzinski et al., 2003). All of the aquatic plant related, pioneer landforms listed in Table 4 can be observed along this reach of the Narew River.

\section{WIDER APPLICATION OF THE MODEL AND ITS RELEVANCE TO MANAGEMENT}

This paper has proposed a conceptual model of vegetation-hydrogeomorphology interactions in river corridors, which defines five potential zones that are dynamic, have fuzzy margins and can exist along longitudinal as well as lateral river corridor gradients. In reality, naturally-functioning river corridors show patchy processes, landforms and habitats, linked by transitional areas, all of which are continually shifting in space and through time. However, the conceptual model simplifies this complexity by highlighting different vegetation-hydrogeomorphology interaction 'regimes' that are distributed across river corridors. The model conceptualises broad aggregate zones where particular hydrogeomorphological processes dominate, which are based on long-established scientific understanding. It then considers the way in which particularly plants, equipped with suitable traits, can act as physical ecosystem engineers, driving characteristic self-organised patterns within each of the zones that are enhanced by vegetation-hydrogeomorphology interactions and characterized by particular types of pioneer landform (e.g. Table 2). Of particular importance is the critical zone (somewhere within zones 1 and 2), where vegetation-hydrogeomorphology interactions occur at the leading edge of vegetation progression from the floodplain into the river channel. These interactions initiate particular types of pioneer landform (Tables 3 and 4) which play a crucial role in determining channel size, form and in some cases river planform pattern.

Schematic conceptual diagrams (Figures 3,4 and 5) have been proposed for three strongly contrasting European biogeographical zones and for rivers with very different reach-scale properties. These illustrate differences in how the zones may be distributed and may function in different environmental contexts. Of course the model greatly simplifies these highly dynamic, spatially complex, systems, but it provides a useful way of developing understanding of such systems and emphasizing all parts of the river corridor not just the river channel and its immediate margins. Although the present analyses were confined to Europe, there is no reason why the conceptual model should not be applied to any naturally-functioning river system on the Earth's surface. Furthermore, once the relevant conceptual diagrams are produced for moisture availability, fluvial disturbance intensity, and vegetation cover and biomass in relation to a new environmental context, and the traits of the potential engineer plants within the local vegetation are recognized, it should be possible to identify the suite of pioneer landforms that occur, and those that drive the critical zone of planthydrogeomorphology interactions. 
Once the conceptual model has been devised for local conditions, it provides a useful tool that can support river and floodplain management. It helps to identify features of natural functioning for different river types within different biogeographical regions, which can form primary targets for restoration or conservation, and it provides a process-based context for devising restoration or conservation approaches.

For example, where the hydrogeomorphological processes remain essentially unmodified but the river corridor has been developed for agriculture; the river bed and margins, and any remnant patches of zones 3, 4, 5 within the broader corridor provide locations where the presence of engineer species and remnant pioneer landforms can be recognized. These provide clues regarding how areas may be best restored or the likely consequences of setting aside areas of agriculture land so that they can revert to a more natural form and function. Such a strategy would avoid wood accumulations or aquatic plants being seen as problems and being removed, or floodplain wetlands being drained or dredged without full consideration of their role in the river corridor ecosystem.

Where hydrogeomorphological processes have been modified, for example by flow regulation, the conceptual modelling approach can be used to understand why the river corridor has changed. The model should support understanding of why different (often alien) plants, with traits that are suited to the new conditions, take on the role of physical ecosystem engineers, changing the type, location, and trajectory of development of pioneer landforms within the different zones. This is particularly important in the critical zone, where a complete transformation of the size, form and vegetation composition of the river and its margins may result from ecosystem engineering by a new set of plant species. Understanding the links between vegetation and hydrogeomorphology may help to devise management solutions that focus on, for example, partly reinstating key processes rather than attempting to directly manage the 'problem' plant species or the sediment accumulating in the river channel.

Finally, where hydrogeomorphological processes are constrained locally by, for example, confining the river and its margins within embankments, the conceptual model may again be useful in understanding the consequence of such confinement for the existence, spatial extent, and physical process intensity within the five zones. Extreme confinement could remove all functioning zones apart from 1 and 2, and could increase flow depth, velocity and shear stresses in those zones to such an extent that all vegetated pioneer landforms are removed by floods and as a result no true two-way interactions between vegetation and hydrogeomorphology persist. Alternatively, small areas of zone 3 may develop on bar tops, but their character is likely to be grossly simplified in comparison with a naturally-functioning zone 3 at the same location.

The conceptual model represents a great simplification of reality, but if used carefully it is a potentially valuable means of developing understanding of river corridor functioning. A goal for the future should be to try to represent the processes within the model in a more quantitative way using both real-world measurements and modelling, so that the consequences of changes in hydrogeomorphological processes or species invasions can be investigated more precisely.

\section{ACKNOWLEDGEMENTS}

The work leading to this paper has received funding from the European Union's FP7 programme under Grant Agreement No. 282656 (REFORM).

\section{REFERENCES}

Abbe TB, Montgomery DR. 2003. Patterns and processes of wood debris accumulation in the Queets river basin, Washington. Geomorphology 51: 81-107.

Baattrup-Pedersen A, Szoszkiewicz K, Nijboer R, O'Hare M, Ferreira T. 2006. Macrophyte communities in unimpacted European streams: variability in assemblage patterns, abundance and diversity. Hydrobiologia 566: 179-196. 
Banaszuk H. 1996. Paleografia. Naturalne i antropogeniczne przekształcenia doliny Górnej Narwi. Wydawnictwo Ekonomia i Środowisko, Białystok, 1-213.

Bertoldi W, Gurnell AM, Surian N, Tockner K, Zanoni L, Ziliani L, Zolezzi G. 2009. Understanding reference processes: linkages between river flows, sediment dynamics and vegetated landforms along the Tagliamento River, Italy. River Research and Applications 25: 501-516.

Bertoldi W, Welber M, Gurnell AM, Mao L, Comiti F, Tal M. (2015) Physical modelling of the combined effect of vegetation and wood on river morphology. Geomorphology, 246: 178-187.

Booth EG, Loheide SP. 2012. Comparing surface effective saturation and depth-to-water-level as predictors of plant composition in a restored riparian wetland. Ecohydrology 5: 637-647.

Bornette G, Tabacchi E, Hupp C, Puijalon S, Rostan JC. 2008. A model of plant strategies in fluvial hydrosystems. Freshwater Biology 53: 1692-1705.

Braatne JH, Jamieson R, Gill KM, Rood SB. 2007. Instream flows and the decline of riparian cottonwoods along the Yakima River, Washington, USA. River Res Appl 23: 247-267.

Brayshaw AC, Frostick LE, Reid I. 1983. The hydrodynamics of particle clusters and sediment entrainment in coarse alluvial channels. Sedimentology 30: 137-143.

Bussettini M, Lastoria B, Braca G, Mariani S, Venturelli S (2011) Regime Idrologico (in Italian) In: Implementazione della Direttiva 2000/60/CE. Analisi e valutazione degli aspetti idromorfologici. ISPRA, Manuali e Linee Guida. ISBN: 978-88-448-0439-8.

Camporeale C, Perucca E, Ridolfi L, Gurnell AM. 2013. Modeling the interactions between river morphodynamics and riparian vegetation. Reviews of Geophysics 51: paper $2012 R G 000407$.

Charlton R. 2008. Fundamentals of Fluvial Geomorphology. Routledge, Abingdon, UK.

Chin A. 2006. Urban transformation of river landscapes in a global context. Geomorphology 79(3-4): 460-487.

Church M. 1992. Channel morphology and typology In: Callow C, Petts G. (Eds.), The rivers handbook: Hydrological and ecological principles, Oxford: Blackwell, 126-143.

Collins BD, Montgomery DR, Fetherston KL, Abbe TB. 2012. The floodplain large-wood cycle hypothesis: A mechanism for the physical and biotic structuring of temperate forested alluvial valleys in the North Pacific coastal ecoregion. Geomorphology 139-140: 460-470.

Comiti F. 2012. How natural are Alpine mountain rivers? Evidence from the Italian Alps. Earth Surface Processes and Landforms 37(7): 693-707.

Corenblit D, Davies NS, Steiger J, Gibling MR, Bornette G. 2015. Considering river structure and stability in the light of evolution: feedbacks between riparian vegetation and hydrogeomorphology. Earth Surface |processes and Landforms 40, 189-207.

Corenblit D, Steiger J, Gurnell AM, Naiman RJ. 2009. Plants intertwine fluvial landform dynamics with ecological succession and natural selection: a niche construction perspective for riparian systems. Glob Ecol Biogeogr 18(4): 507-520.

Corenblit D, Tabacchi E, Steiger J, Gurnell AM. 2007. Reciprocal interactions and adjustments between fluvial landforms and vegetation dynamics in river corridors: A review of complementary approaches. Earth-Science Reviews 84(1-2): 56-86.

Cotton JA, Wharton G, Bass JAB, Heppell CM, Wotton RS. 2006. The effects of seasonal changes to in-stream vegetation cover on patterns of flow and accumulation of sediment. Geomorphology 77: 320-334.

Cunningham SC, Thomson JR, Mac Nally, R, Read J, Baker PJ. 2011. Groundwater change forecasts widespread forest dieback across an extensive floodplain system. Freshwater Biology 56: 1494-1508.

Daniel H, Bernez I, Haury J. 2006. Relationships between macrophytic vegetation and physical features of river habitats: the need for a morphological approach. Hydrobiologia 570: 11-17. 
Davis RJ, Gregory KJ. 1994. A new distinct mechanism of river bank erosion in a forested catchment. Journal of Hydrology 157(1-4): 1-11.

D'Odorico P, Laio F, Porporato A, Ridolfi L, Rinaldo A, Iturbe IR. 2010. Ecohydrology of Terrestrial Ecosystems. Bioscience 60(11): 898-907.

D'Odorico, P., Okin, G.S. and Bestelmeyer, B.T., 2012. A synthetic review of feedbacks and drivers of shrub encroachment in arid grasslands. Ecohydrology 5, 520-530.

Downs PW, Dusterhoff SR, Sears WA. 2013. Reach-scale channel sensitivity to multiple human activities and natural events: Lower Santa Clara River, California, USA. Geomorphology 189: 121134.

Edwards PJ, Kollmann J, Gurnell AM, Petts GE, Tockner K, Ward JV. 1999. A conceptual model of vegetation dynamics on gravel bars of a large Alpine river. Wetlands Ecology and Management, 7: 141-153.

Erskine W, Chalmers A, Keene A, Cheetham M, Bush R. 2009. Role of a rheophyte in bench development on a sand-bed river in southeast Australia. Earth Surface Processes and Landforms 34(7): 941-953.

Evette, A., Balique, C., Lavaine, C., Rey, F. and Prunier, P., 2012. Using ecological and biogeographical features to produce a typology of the plant species used in bioengineering for riverbank protection in Europe. River Research and Applications 28(10): 1830-1842.

Francis RA, Corenblit D, Edwards PJ. 2009. Perspectives on biogeomorphology, ecosystem engineering and self-organisation in island-braided fluvial ecosystems. Aquatic Sciences 71: 290304.

Friedman JM, Osterkamp WR, Lewis WM. 1996. The role of vegetation and bed-level fluctuations in the process of channel narrowing. Geomorphology 14: 341-351.

García-Arias A, Francés F, Ferreira T, Egger G, Martínez-Capel F, Garófano-Gómez V, AndrésDoménech, I., Politti, E., Rivaes, R., Rodríguez-González, P.M. 2013. Implementing a dynamic riparian vegetation model in three European river systems. Ecohydrology 6: 635-651.

Gradziński R. 2004. Anastomozujący system Narwi na obszarze Narwiańskiego Parku Narodowego. [w:] Banaszuk H. (red.), Przyroda Podlasia: Narwiański Park Narodowy. Narwiański Park Narodowy, Kurowo, 70-79.

Gradziński R, Baryla J, Doktor M, Gmur D, Gradzinski M, Kedzior A, et al. 2003. Vegetation-controlled modern anastomosing system of the upper Narew River (NE Poland) and its sediments. Sedimentary Geology 157(3-4): 253-276.

Graf WL. 1978. Fluvial adjustments to the spread of tamarisk in the Colorado Plateau region. Geological Society of America Bulletin 89: 1491-1501.

Graf WL. 2006. Downstream hydrologic and geomorphic effects of large dams on American rivers. Geomorphology 79(3-4): 336-360.

Gregory KJ, Gurnell AM, Hill CT. 1985. The permanence of debris dams related to river channel processes. Hydrological Sciences Journal 30: 371-381.

Gregory S, Ashkenas L, Oetter D, Minear P, Wildman K. 2002. Historical Willamette River Channel Change. In: Willamette River basin Planning Atlas: Trajectories of Environmental and Ecological Change, (Hulse D, Gregory S, Baker J, eds):Oregon State University Press, 18-25.

Griffin ER, Smith JD. 2004. Floodplain stabilization by woody riparian vegetation during an extreme flood. In: S.J. Bennett and A. Simon (Eds.), Riparian Vegetation and Fluvial Geomorphology. Water Science and Application. American Geophysical Union, Washington, D.C., pp. 221-236.

Gurnell AM. 2007. Analogies between mineral sediment and vegetative particle dynamics in fluvial systems. Geomorphology 89: 9-22.

Gurnell AM. 2014. Plants as river system engineers. Earth Surface Processes and Landforms 39: 425. 
Gurnell AM, Bertoldi W, Corenblit D. 2012. Changing river channels: the roles of hydrological processes, plants and pioneer landforms in humid temperate, mixed load, gravel bed rivers. Earth Science Reviews 111: 129-141.

Gurnell AM, Grabowski RC. 2015. Vegetation-hydrogeomorphology interactions in a low-energy, human-impacted river. River Research and Applications, DOI: 10.1002/rra.2922.

Gurnell AM, O'Hare JM, O'Hare MT, Dunbar MJ, Scarlett PM. 2010. An exploration of associations between assemblages of aquatic plant morphotypes and channel geomorphological properties within British rivers. Geomorphology 116: 135-144.

Gurnell AM, O'Hare MT, O'Hare JM, Scarlett P, Liffen TMR. 2013. The geomorphological context and impact of the linear emergent macrophyte, Sparganium erectum L.: a statistical analysis of observations from British rivers. Earth Surface Processes and Landforms 38(15): 1869-1880.

Gurnell A, Petts G. 2006. Trees as riparian engineers: The Tagliamento River, Italy. Earth Surface Processes and Landforms 31(12): 1558-1574.

Gurnell AM, Petts GE, Hannah DM, Smith BPG, Edwards PJ, Kollmann J, Ward, JV, Tockner, K. 2001. Riparian vegetation and island formation along the gravel-bed Fiume Tagliamento, Italy. Earth Surface Processes and Landforms 26(1): 31-62.

Gurnell AM, Piégay H, Swanson FJ, Gregory SV. 2002. Large wood and fluvial processes. Freshwater Biology 47(4): 601-619.

Gurnell AM, Tockner K, Edwards PJ, Petts GE. 2005. Effects of deposited wood on biocomplexity of river corridors. Frontiers in Ecology and Environment 3(7): 377-382.

Hendriks MR. 2010. Introduction to physical hydrology. Oxford, Oxford University Press.

Hohensinner S, Jungwirth M, Muhar S, Schmutz S. 2011. Spatio-temporal habitat dynamics in a changing Danube River landscape 1812-2006. River Research and Applications, 27:939-955.

Hughes FMR, González del Tánago M, Mountford JO. 2012. Restoring floodplain forests in Europe. In: A goal-oriented approach to forest landscape restoration, (Stanturf J, Madsen P, Lamb D, eds). Dordrecht:Springer, 393-422.

Hughes FMR, Rood SB. 2003. Allocation of River Flows for Restoration of Floodplain Forest Ecosystems: A Review of Approaches and Their Applicability in Europe. Environ Manage 32(1): 12-33.

Hupp CR. 1983. Vegetation pattern on channel features in the Passage Creek Gorge, Virginia. Castanea 48: 62-72.

Hupp CR. 1986. Upstream variations in bottomland vegetation patterns, northwestern Virginia. Bulletin of the Torrey Botanical Club 113: 421-430.

James, L.A., Marcus, W.A., 2006. The human role in changing fluvial systems: retrospect, inventory and prospect. Geomorphology 79, 152-171.

Jang CL, Shimizu Y. 2007. Vegetation effects on the morphological behavior of alluvial channels. Journal of Hydraulic Research 45: 763-772.

Johnson WC. 1994. Woodland Expansions in the Platte River, Nebraska: Patterns and Causes. Ecological Monographs 64: 45-84.

Jones CG, Lawton JH, Shachak M. 1994. Organisms as ecosystem engineers. Oikos 69: 373-386.

Jones CG, Gutiérrez JL, Byers JE, Crooks JA, Lambrinos JG, Talley TS. 2010. A framework for understanding physical ecosystem engineering by organisms. Oikos 119: 1862-1869.

Kath J, Reardon-Smith K, Le Brocque AF, Dyer FJ, Dafny E, Fritz L, Batterham M. 2014. Groundwater decline and tree change in floodplain landscapes: Identifying non-linear threshold responses in canopy condition. Global Ecology and Conservation 2: 148-160.

Klimaszewski M. 1981. Geomorfologia. PWN Warszawa, 1-1063. 
Kondolf GM, Curry RR. 1986. Channel erosion along the Carmel River, Monterey County, California. Earth Surface Processes and Landforms 11: 307-319.

Kondolf MG, Piégay H. (eds.) 2016. Tools in Fluvial Geomorphology. Wiley, in press.

Lytle DA, Merritt DM. 2004. Hydrologic regimes and riparian forests: A structured population model for cottonwood. Ecology 85(9): 2493-2503.

Madej MA, Weaver WE, Hagans DK. 1994. Analysis of bank erosion on the Merced River, Yosemite Valley, Yosemite-National-Park, California, USA. Environmental Management 18: 235-250.

McCarthy TS, Ellery WN, Dangerfield JM. 1998. The role of biota in the initiation and growth of islands of the floodplain of the Okavango alluvial fan, Botswana. Earth Surface Processes and Landforms 23: 291-316.

McKenney R, Jacobson RB, Wertheimer RC. 1995. Woody vegetation and channel morphogenesis in low-gradient, gravel-bed streams in the Ozark Plateaus, Missouri and Arkansas. Geomorphology 13(1-4): 175-198.

McShane RR, Auerbach DA, Friedman JM, Auble GT, Shafroth PB, Merigliano MF, Scott ML, LeRoy Poff N. 2015. Distribution of invasive and native riparian woody plants across the western USA in relation to climate, river flow, floodplain geometry and patterns of introduction. Ecography 38: DOI: $10.1111 /$ ecog. 01285 .

Merritt DM, Cooper DJ. 2000. Riparian vegetation and channel change in response to river regulation: a comparative study of regulated and unregulated streams in the Green River Basin, USA. Regulated Rivers: Research \& Management 16: 543-564.

Nanson GC. 1981. New evidence of scroll-bar formation on the Beatton River. Sedimentology 28(6): 889-891.

Nanson, G. and Beach, H.F., 1977. Forest succession and sedimentation on a meandering-river floodplain, northeast British Columbia, Canada. Journal of Biogeography, 4: 229-251.

Nilsson C, Svedmark M. 2002. Basic Principles and Ecological Consequences of Changing Water Regimes: Riparian Plant Communities. Environmental Management 30(4): 468-480.

Odling-Smee FJ, Laland KN, Feldman MW. 1996. Niche construction. The American Naturalist 147(4): 641-648.

Osterkamp WR, 1998. Processes of fluvial island formation, with examples from Plum Creek, Colorado and Snake River, Idaho. Wetlands, 18: 530-545.

Osterkamp WR, Hupp CR. 2010. Fluvial processes and vegetation -- Glimpses of the past, the present, and perhaps the future. Geomorphology 116: 274-285.

Osterkamp WR, Hupp CR, Stoffel M. 2012. The interactions between vegetation and erosion: new directions for research at the interface of ecology and geomorphology. Earth Surface Processes and Landforms 37: 23-36.

Page K, Nanson G. 1982. Concave-bank benches and associated floodplain formation. Earth Surface Processes and Landforms 7: 529-543.

Perona P, Molnar P, Crouzy B, Perucca E, Jiang Z, McLelland S, Wuthrich D, Edmaier K, Francis R, Camporeale C, Gurnell AM. 2012. Biomass selection by floods and related timescales: Part 1. Experimental observations. Advances in Water Resources, 39: 85-96.

Pettit NE, Froend RH, Davies PM. 2001. Identifying the natural flow regime and the relationship with riparian vegetation for two contrasting western Australian rivers. Regulated Rivers, Research and Management 17(3): 201-215.

Polce C, Kunin WE, Biesmeijer JC, Dauber J, Phillips OL, Network AFS. 2011. Alien and native plants show contrasting responses to climate and land use in Europe. Global Ecology and Biogeography 20: 367-379.

Rietkerk M, Dekker SC, de Ruiter PC, van de Koppel J. 2004. Self-Organized Patchiness and Catastrophic Shifts in Ecosystems. Science 305: 1926-1929. 
Rietkerk M, Ketner P, Burger J, Hoorens B, Olff H. 2000. Multiscale soil and vegetation patchiness along a gradient of herbivore impact in a semi-arid grazing system in West Africa. Plant Ecology 148: 207-224.

Rietkerk M, van de Koppel J. 2008. Regular pattern formation in real ecosystems. Trends in Ecology and Evolution 23: 169-175.

Rinaldi M, Gurnell AM, González Del Tánago M, Bussettini M, Hendriks D. 2015. Classification of river morphology and hydrology to support management and restoration, in review.

Rinaldi M, Wyzga B, Surian N. 2005. Sediment mining in alluvial channels: Physical effects and management perspectives. River Research and Applications 21(7): 805-828.

Riis T, Biggs BJF. 2003. Hydrologic and hydraulic control of macrophyte establishment and performance in streams. Limnology and Oceanography 48(4): 1488-1497.

Rivas-Martinez S, Penas A, Díaz TE. 2004. Biogeographic Map of Europe. http://www.globalbioclimatics.org/form/bg_med.htm, accessed 11 July 2015.

Robertson KM, Augspurger CK. 1999. Geomorphic processes and spatial patterns of primary forest succession on the Bogue Chitto River, USA. Journal of Ecology 87: 1052-1063.

Rood SB, Gourley CR, Ammon EM, Heki LG, Klotz JR, Morrison ML, Mosley D, Scoppettone GG, Swanson S, Wagner PL. 2003. Flows for Floodplain Forests: A Successful Riparian Restoration. BioScience 53(7): 647-656.

Rood SB, Mahoney JM. 1995. River damming and riparian cottonwoods along the Marias River, Montana. Rivers 5: 195-207.

Rood SB, Samuelson GM, Braatne JH, Gourley CR, Hughes FMR, Mahoney JM. 2005. Managing river flows to restore floodplain forests. Frontiers in Ecology and the Environment 3(4): 193-201.

Rowntree K. 1991. An assessment of the potential impact of alien invasive vegetation on the geomorphology of river channels in South Africa. South African Journal of Aquatic Science 17: 2843.

Rutherfurd ID, Grove JR. 2004. The influence of trees on stream bank erosion: Evidence from rootplate abutments. In: Riparian Vegetation and Fluvial Geomorphology, Vol. 8, (Bennett SJ, Simon A, eds). Washington:Amer Geophysical Union, 141-152.

Scheffer M, Holmgren M, Brovkin V, Claussen M. 2005. Synergy between small- and large-scale feedbacks of vegetation on the water cycle. Global Change Biology 11(7): 1003-1012.

Schoelynck J, de Groote T, Bal K, Vandenbruwaene W, Meire P, Temmerman S. 2012. Self-organised patchiness and scale-dependent bio-geomorphic feedbacks in aquatic river vegetation. Ecography 35: 760-768.

Solari L, Van Oorschot M, Hendriks D, Rinaldi M, Vargas-Luna A. 2015. Advances on modelling riparian vegetation-hydromorphology interactions. River Research and Applications, DOI: 10.1002/rra.2910.

Sponseller RA, Heffernan JB, Fisher SG. 2013. On the multiple ecological roles of water in river networks. Ecosphere, 4: article 17, 14 pages.

Steiger J, Tabacchi E, Dufour S, Corenblit D, Peiry JL. 2005. Hydrogeomorphic processes affecting riparian habitat within alluvial channel-floodplain river systems: a review for the temperate zone. River Research and Applications 21: 719-737.

Stromberg JC. 2001. Restoration of riparian vegetation in the south-western United States: importance of flow regimes and fluvial dynamism. Journal of Arid Environments 49(1): 17-34.

Stromberg JC. Bagstad KJ, Leenhouts JM, Lite SJ, Makings E. 2005. Effects of stream flow intermittency on riparian vegetation of a semiarid region river (San Pedro River, Arizona). River Research and Applications 21: 925-938.

Stromberg, J.C., Lite, S.J. and Dixon, M.D., 2010. Effects of stream flow patterns on riparian vegetation of a semiarid river: Implications for a changing climate. River Research and Applications, 26(6): 712-729. 
Stromberg JC, Patten DT. 1996. Instream flow and cottonwood growth in the eastern Sierra Nevada of California, USA. Regulated Rivers: Research \& Management 12: 1-12.

Surian N, Rinaldi M. 2003. Morphological response to river engineering and management in alluvial channels in Italy. Geomorphology 50(4): 307-326.

Tal M, Paola C. 2010. Effects of vegetation on channel morphodynamics: results and insights from laboratory experiments. Earth Surface Processes and Landforms 35: 1014-1028.

Tockner K, Stanford JA. 2002. Riverine flood plains: present state and future trends. Environmental Conservation 29(3): 308-330.

Tooth, S. and Nanson, G.C., 1999. Anabranching rivers on the Northern Plains of arid central Australia. Geomorphology, 29: 211-233.

Uhlenbrook S. (Ed.) The Science of Hydrology. Volume 2 of Wilderer P. (Ed.) Treatise on Water Science, Academic Press: Oxford, 546 pages.

Wainwright J, Parsons AJ, Schlesingeer WH, Abrahams AD. 2002. Hydrology-vegetation interactions in areas of discontinuous flow on a semi-arid bajada, Southern New Mexico. Journal of Arid Environments 51(3): 319-338.

Ward JV, Tockner K, Arscott DB, Claret C. 2002. Riverine landscape diversity. Freshwater Biology 47: 517-539.

Wetzel PR, van der Valk AG, Newman S, Gawlik DE, Troxler Gann T, Coronado-Molina CA, et al. 2005. Maintaining tree islands in the Florida Everglades: nutrient redistribution is the key. Frontiers in Ecology and Environment 3: 370-376.

Wohl E. 2006. Human impacts to mountain streams. Geomorphology 79(3-4): 217-248.

Wohl E. (ed.) 2013. Fluvial Geomorphology. Volume 9 of Schroder, J. (ed.) Treatise on Geomorphology, Academic Press, San Diego, Ca., 860 pages.

Wyżga B, Zawiejska J, Radecki-Pawlik A, Hajdukiewicz H. 2012. Environmental change, hydromorphological reference conditions and the restoration of Polish Carpathian rivers. Earth Surface Processes and Landforms 37: 1213-1226. 
Table 1 Region to reach scale-dependent influences of water-related physical processes on vegetation.

\begin{tabular}{|c|c|c|c|}
\hline $\begin{array}{c}\text { Spatial unit } \\
\text { (indicative spatial } \\
\text { scale) }\end{array}$ & Climate & Moisture Availability & Fluvial Disturbance \\
\hline $\begin{array}{l}\text { Region } \\
\left(>10^{5} \mathrm{~km}^{2}\right)\end{array}$ & $\begin{array}{l}\text { Macroclimate } \\
\text { (precipitation and } \\
\text { temperature regimes) }\end{array}$ & & \\
\hline $\begin{array}{l}\text { Catchment } \\
\left(10^{2}-10^{5} \mathrm{~km}^{2}\right)\end{array}$ & $\begin{array}{l}\text { Macroclimate } \\
\text { (precipitation, } \\
\text { temperature and wind } \\
\text { regimes related to } \\
\text { broad topographic } \\
\text { setting) }\end{array}$ & $\begin{array}{l}\text { Geological and } \\
\text { topographic influences } \\
\text { on water retention, } \\
\text { including deep } \\
\text { percolation and } \\
\text { aquifers }\end{array}$ & $\begin{array}{l}\text { Water balance and } \\
\text { runoff responsiveness } \\
\text { reflecting catchment } \\
\text { size, geology, } \\
\text { topography and land } \\
\text { cover }\end{array}$ \\
\hline $\begin{array}{l}\text { Landscape Unit } \\
\left(10^{2}-10^{3} \mathrm{~km}^{2}\right)\end{array}$ & $\begin{array}{l}\text { Mesoclimate (sub- } \\
\text { catchment } \\
\text { precipitation, } \\
\text { temperature and wind } \\
\text { conditions moderated } \\
\text { by elevation, } \\
\text { topographic form and } \\
\text { orientation) }\end{array}$ & $\begin{array}{l}\text { Impacts of topography, } \\
\text { geology, soils and land } \\
\text { cover on water } \\
\text { infiltration and } \\
\text { moisture retention, } \\
\text { recharge and } \\
\text { depletion }\end{array}$ & $\begin{array}{l}\text { Magnitude, frequency } \\
\text { and duration of water } \\
\text { and sediment delivery } \\
\text { to the river corridor } \\
\text { (including droughts, } \\
\text { avalanches, mudflows, } \\
\text { organic debris flows) } \\
\text { influenced by geology, } \\
\text { topography, land cover } \\
\text { and management }\end{array}$ \\
\hline $\begin{array}{l}\text { Segment } \\
\left(10^{1}-10^{2} \mathrm{~km}\right)\end{array}$ & $\begin{array}{l}\text { Meso-climate (local } \\
\text { precipitation, } \\
\text { temperature and wind } \\
\text { conditions moderated } \\
\text { by elevation, } \\
\text { topographic form and } \\
\text { orientation, and valley } \\
\text { setting) }\end{array}$ & $\begin{array}{l}\text { Hillslope hydrology, } \\
\text { river flow regimes and } \\
\text { water flow modification } \\
\text { by river-floodplain } \\
\text { width. Segment-scale } \\
\text { (alluvial aquifer) } \\
\text { groundwater - surface } \\
\text { water interactions } \\
\text { (GSI) }\end{array}$ & $\begin{array}{l}\text { Valley gradient and } \\
\text { river entrenchment } \\
\text { that moderate the local } \\
\text { river flow and } \\
\text { sediment transport } \\
\text { regimes (including } \\
\text { floods and droughts, } \\
\text { sediment and plant } \\
\text { material erosion, } \\
\text { transport, and storage) }\end{array}$ \\
\hline $\begin{array}{l}\text { Reach } \\
\left(10^{-1}-10^{1} \mathrm{~km}\right)\end{array}$ & $\begin{array}{l}\text { Micro-climate (local } \\
\text { climate conditions } \\
\text { incorporating impacts } \\
\text { of vegetation shading, } \\
\text { roughness and } \\
\text { transpiration, and } \\
\text { water body } \\
\text { evaporation). }\end{array}$ & $\begin{array}{l}\text { Cross sectional } \\
\text { channel-floodplain } \\
\text { form and sedimentary } \\
\text { structure, texture, } \\
\text { permeability. Reach- } \\
\text { scale GSI }\end{array}$ & $\begin{array}{l}\text { Channel gradient, size, } \\
\text { type / morphology, bed } \\
\text { and bank materials } \\
\text { (including sediment } \\
\text { calibre, cohesion, } \\
\text { erodibility, stream } \\
\text { power in relation to } \\
\text { reach-scale water, } \\
\text { sediment, plant } \\
\text { material dynamics) }\end{array}$ \\
\hline
\end{tabular}


Table 2 Examples of patterned vegetation and micro- to meso-morphology (pioneer landforms) formed by self-organisation in different hydrological and fluvial geomorphological contexts.

\begin{tabular}{|c|c|c|}
\hline $\begin{array}{l}\text { Environmental } \\
\text { Setting }\end{array}$ & $\begin{array}{c}\text { Vegetation-Hydromorphology Interaction-Feedback } \\
\text { Processes }\end{array}$ & Source \\
\hline \multirow[t]{2}{*}{$\begin{array}{l}\text { Drylands } \\
\text { (zone } 5 \text { and in some } \\
\text { cases zones } 4 \text { and } 3 \text { ) }\end{array}$} & $\begin{array}{l}\text { The presence of vegetation increases water infiltration (roots) } \\
\text { and decreases soil evaporation. Vegetation extracts moisture } \\
\text { from surrounding areas to support evapotranspiration, while } \\
\text { differences in water infiltration reduce the supply of moisture to } \\
\text { surrounding areas. Thus patches of vegetation persist once } \\
\text { present, but bare soil is too hostile for recolonization once } \\
\text { vegetation is removed. }\end{array}$ & $\begin{array}{l}\text { Rietkerk et al., } \\
2000 .\end{array}$ \\
\hline & $\begin{array}{l}\text { Okavango Delta: Termite mounds accumulate nutrients and } \\
\text { become colonized by terrestrial vegetation which attracts } \\
\text { browsers / grazers who further enrich the nutrient supply } \\
\text { leading to island development. }\end{array}$ & $\begin{array}{l}\text { McCarthy et al. } \\
1998 .\end{array}$ \\
\hline \multirow{2}{*}{$\begin{array}{l}\text { Wetlands } \\
\text { (zones } 5 \text { and } 4 \text { in wet } \\
\text { environments, zones } \\
4 \text { and } 3 \text { in less wet } \\
\text { environments) }\end{array}$} & $\begin{array}{l}\text { Mires often display hummocky / ridged patterning as a result of } \\
\text { positive feedback between plant productivity and groundwater } \\
\text { depth. This reflects increased production of vascular plants on } \\
\text { drier sites. }\end{array}$ & $\begin{array}{l}\text { Rietkerk et al., } \\
2004 .\end{array}$ \\
\hline & $\begin{array}{l}\text { Florida Everglades: Subsurface flows of water are induced by } \\
\text { tree evapotranspiration, which redistributes nutrients from } \\
\text { surrounding areas towards tree islands, this increases primary } \\
\text { productivity and peat development which increases the size } \\
\text { and elevation of the tree islands. }\end{array}$ & Wetzel et al., 2005. \\
\hline $\begin{array}{l}\text { Severe fluvial } \\
\text { disturbance dominated } \\
\text { (zone } 2 \text { in strongly } \\
\text { fluvially-disturbed } \\
\text { environments) }\end{array}$ & $\begin{array}{l}\text { Uprooted trees deposited on bars, sprout and produce roots, } \\
\text { the trees are anchored by their roots and their sprouting foliage } \\
\text { traps sediment from water and wind transport leading to island } \\
\text { development. Flowing water is concentrated between the } \\
\text { developing islands during floods leading to scour and } \\
\text { vegetation removal. }\end{array}$ & $\begin{array}{l}\text { Gurnell et al., } 2001 \\
2005 . \\
\text { Francis et al., } 2009\end{array}$ \\
\hline $\begin{array}{l}\text { Submerged } \\
\text { (zone 1) }\end{array}$ & $\begin{array}{l}\text { The main mechanism for pattern formation in aquatic river } \\
\text { vegetation is scale-dependent feedbacks between aquatic } \\
\text { plant growth (submerged and emergent), water flow velocity } \\
\text { and erosion and sedimentation of the river bed. Within } \\
\text { vegetation patches, flow velocity reduction leads to } \\
\text { sedimentation, whereas between patches flow velocity is } \\
\text { increased resulting in less sedimentation or scour. Plant } \\
\text { survival is increased within patches and decreased between } \\
\text { patches. }\end{array}$ & $\begin{array}{l}\text { Schoelynck et al., } \\
2012 .\end{array}$ \\
\hline
\end{tabular}


Table 3. Pioneer landforms induced by trees within the critical zone of small, intermediate and large rivers, where the river size is relative to the size of the plants or wood pieces driving landform development

\begin{tabular}{|c|c|c|}
\hline $\begin{array}{l}\text { Relative river } \\
\text { size }\end{array}$ & $\begin{array}{c}\text { Large Wood (unless stated otherwise, after Abbe and } \\
\text { Montgomery, 2003) }\end{array}$ & Trees, Shrubs, Living wood, Riparian tree seedlings \\
\hline \multirow[t]{3}{*}{ Small rivers } & In situ jams created by predominantly (autochthonous) wood & In situ features created by individual trees \\
\hline & $\begin{array}{l}\text { Bank input jams: produced by trees or other large wood pieces } \\
\text { falling into the river from the bank and remaining in situ because of } \\
\text { their large size relative the channel. They may induce significant } \\
\text { sediment retention, and their local strengthening of the river bank } \\
\text { can drive lateral channel migration. }\end{array}$ & $\begin{array}{l}\text { Bank buttressing: The roots of individual trees can buttress } \\
\text { the river bank, strongly influencing bank erosion and bank } \\
\text { profile development (e.g. Davis and Gregory, 1994, } \\
\text { Rutherfurd and Grove, 2004, Gurnell and Grabowski, 2015) }\end{array}$ \\
\hline & $\begin{array}{l}\text { Log steps: produced by tree fall with little downstream movement, } \\
\text { partly or completely blocking the flow and trapping bed material to } \\
\text { form a distinct step in the bed profile. }\end{array}$ & $\begin{array}{l}J \text {-shaped trees: often develop as a result of interaction } \\
\text { between tree growth and bank erosion / movement. This, } \\
\text { coupled with the ability of many riparian tree species to } \\
\text { produce adventitious roots, can lead to roots shooting from } \\
\text { below the } J \text { in the trunk to penetrate the river bank and bed } \\
\text { and create complex wood-dominated bank profiles (e.g. } \\
\text { Gurnell and Grabowski, 2015). }\end{array}$ \\
\hline \multirow[t]{3}{*}{$\begin{array}{l}\text { Intermediate } \\
\text { rivers }\end{array}$} & $\begin{array}{l}\text { Combination jams of locally produced (autochthonous) wood } \\
\text { and large quantities of mobile (allochthonous) wood. }\end{array}$ & $\begin{array}{l}\text { Combination jams with living tree trunks, trailing } \\
\text { branches and exposed roots acting as key pieces. }\end{array}$ \\
\hline & $\begin{array}{l}\text { Flow deflection jams: developments of the bank input jams present } \\
\text { in 'small' rivers. Composed of key pieces delivered by local wood or } \\
\text { tree fall that partly blocks the channel, coupled with large quantities } \\
\text { of wood pieces from upstream that become racked against the key } \\
\text { pieces, and many other smaller pieces jammed into the wood matrix } \\
\text { along with sediment and seeds. These can be large features } \\
\text { (associated with 'intermediate' or 'large' rivers) that deflect flows } \\
\text { causing significant bank erosion and pool development; bench } \\
\text { development within and behind the jam; and channel migration. } \\
\text { Vegetation colonises the benches and can eventually aggrade into } \\
\text { the floodplain. }\end{array}$ & \multirow[t]{2}{*}{$\begin{array}{l}\text { Flow deflection, channel spanning and valley jams: all involve } \\
\text { the retention of seeds and may also involve wood capable of } \\
\text { sprouting. The resulting development of a vegetation cover } \\
\text { supports surface aggradation and accelerates landform } \\
\text { development. Where dead wood decays slowly or vegetation } \\
\text { develops rapidly, the features can persist for long periods, } \\
\text { becoming incorporated into the floodplain (Collins et al., } \\
\text { 2012) }\end{array}$} \\
\hline & $\begin{array}{l}\text { Channel spanning active / complete jams: as river channels widen } \\
\text { and channel gradients reduce, log steps transition into channel } \\
\text { spanning log jams in which few wood pieces remain in situ but are } \\
\text { trapped by larger, channel-spanning pieces, standing trees or } \\
\text { irregularities in the channel margin. These have been classified as }\end{array}$ & \\
\hline
\end{tabular}


'active' when they form a sufficient barrier to induce a step in the water surface profile at baseflow, and 'complete' if they do not (Gregory et al., 1985). In addition to inducing steps in the bed profile, they may cause the development of significant plunge pools, bars and bank undercutting / erosion.

\begin{tabular}{|c|c|c|}
\hline $\begin{array}{l}\text { Intermediate } \\
\text { rivers(ctd.) }\end{array}$ & $\begin{array}{l}\text { Valley jams: enormous accumulations of wood that extend well } \\
\text { beyond the river channel. They can be produced when large trees } \\
\text { fall, are toppled by the wind, or are contributed by hillslope } \\
\text { landslides or catastrophic failures along tributary channels. They } \\
\text { block the channel sufficiently to divert flow, leading to widespread } \\
\text { undermining of other trees and the trapping of large quantities of } \\
\text { mobile wood to form enormous complex jams. These modify the } \\
\text { river's long-profile and produce a complex of hydraulic habitats that } \\
\text { lead to wood and sediment retention, vegetation colonisation and a } \\
\text { mosaic of aquatic and riparian landforms. }\end{array}$ & \\
\hline \multirow[t]{3}{*}{ Large rivers } & Allochthonous jams & Allochthonous living wood and tree seedling features \\
\hline & $\begin{array}{l}\text { Flood jams: created when wood accumulates beyond the river } \\
\text { channel during floods, forming wood ridges and wood piles trapped } \\
\text { around or between standing trees. A special, large case of wood } \\
\text { ridge development occurs when flood delivery of wood combines } \\
\text { with debris torrents from surrounding hillslopes. Similarly wood plugs } \\
\text { can form at the entrance to distributary channels. }\end{array}$ & $\begin{array}{l}\text { Flood jams: can sprout or support seed germination leading } \\
\text { to local thickets of floodplain vegetation that can retain } \\
\text { sediment to form elevated vegetated zones within the } \\
\text { floodplain. }\end{array}$ \\
\hline & $\begin{array}{l}\text { Bar apex jams: are initiated by a key piece of wood, usually an } \\
\text { entire tree that snags on the upstream face or crest of a mid- } \\
\text { channel, side or point bar. The wood induces flow divergence and } \\
\text { acceleration around the upstream-facing root wad, leading to the } \\
\text { scour of a pool, and flow deceleration and deposition of finer } \\
\text { sediment around the tree trunk. As wood pieces are trapped by the } \\
\text { root wad, the processes of scour pool and bar development are } \\
\text { accentuated. }\end{array}$ & $\begin{array}{l}\text { Pioneer islands: seed germination on the accumulating wood } \\
\text { pieces and finer sediment retained by bar apex jams (Abbe } \\
\text { and Montgomery, 2003) can lead to pioneer island } \\
\text { development, but this processes is much quicker if the wood, } \\
\text { including the tree key piece, can sprout (Edwards et al., } \\
\text { 1999). This is the process that drives vegetation-fluvial } \\
\text { process interactions in the critical zone of many large rivers. }\end{array}$ \\
\hline
\end{tabular}




\begin{tabular}{|c|c|c|}
\hline & $\begin{array}{l}\text { Bench jams: form where wood pieces, oriented approximately } \\
\text { parallel to the flow, become jammed in irregularities in the channel } \\
\text { margins. The key pieces create a sheltered area within the channel } \\
\text { margins, where smaller wood pieces, sediment and seeds can } \\
\text { accumulate, leading to wood-associated bench development, and } \\
\text { possibly lateral channel migration. }\end{array}$ & $\begin{array}{l}\text { Bench jams: sprout to provide root-reinforced, vegetated } \\
\text { features that develop and aggrade more rapidly than their } \\
\text { 'dead' wood counterparts, extending floodplain and island } \\
\text { margins (Erskine, 2009). }\end{array}$ \\
\hline & $\begin{array}{l}\text { Meander jams: develop on the outer and downstream banks of } \\
\text { meander bends where mobile wood becomes trapped against, } \\
\text { within and on the bank, forming an erosion-resistant barrier that } \\
\text { influences the development of the river bend, often resulting in fine } \\
\text { sediment bar and bench development as well as deep pools in the } \\
\text { river bed. }\end{array}$ & $\begin{array}{l}\text { Meander scrolls: where wood accumulates on the inner } \\
\text { banks of meander bends, it often interacts with fluvial } \\
\text { processes to form the core of scroll bars (Nanson, 1981; } \\
\text { Gurnell et al., 2001). If this buried wood sprouts, the scrolls } \\
\text { aggrade rapidly into vegetated ridges (e.g. McKenney et al., } \\
\text { 1995) reinforced by adventitious roots (Gurnell and Petts, } \\
\text { 2006) that accelerate bend development and migration. }\end{array}$ \\
\hline & $\begin{array}{l}\text { Counterpoint jams: form within the upstream, concave, bank of river } \\
\text { bends on large, low gradient meandering channels, where whole } \\
\text { trees and large wood pieces accumulate in dead zones along with } \\
\text { large quantities of fine sediment and organic material. These } \\
\text { accumulations develop into vegetated counterpoint bars and } \\
\text { benches (Page and Nanson, 1982). }\end{array}$ & $\begin{array}{l}\text { Counterpoint scrolls: develop in dead zones on the outer } \\
\text { bank of meanders (Page and Nanson, 1982). Vegetation } \\
\text { growth from seedlings deposited in counterpoint dead zones } \\
\text { may be sufficiently rapid and robust to drive scroll } \\
\text { development, but the process is greatly accelerated when the } \\
\text { deposited wood can sprout. }\end{array}$ \\
\hline $\begin{array}{l}\text { Large rivers } \\
\text { (ctd.) }\end{array}$ & & $\begin{array}{l}\text { Seedling-induced scroll bars and levées: can be initiated in } \\
\text { rivers that support a more predictable annual flow regime } \\
\text { with a distinct annual flow peak (usually the spring snowmelt } \\
\text { peak) and a lower flood regime than those where sprouting } \\
\text { wood is required to produce these features very quickly. } \\
\text { Sediment is trapped as the seedlings grow close to the low } \\
\text { flow channel margins to form ridge-like features at elevations } \\
\text { that are sufficiently low for an adequate moisture supply but } \\
\text { sufficiently high to avoid seedling uprooting by flow pulses } \\
\text { (Gurnell, 2014). }\end{array}$ \\
\hline
\end{tabular}


Table 4. A three stage sequence of pioneer landforms induced by aquatic plants within the critical zone of low energy rivers, and a potential fourth stage of levée construction within zone 3 of extremely low energy anastomosing systems.

\begin{tabular}{|c|c|}
\hline $\begin{array}{l}\text { Stage and } \\
\text { Feature }\end{array}$ & Description \\
\hline $\begin{array}{l}\text { Feature stage (i): } \\
\text { Submerged bars } \\
\text { and shelves }\end{array}$ & $\begin{array}{l}\text { These form in zone 1, usually in association with stands of emergent } \\
\text { macrophytes along the channel margins, where sediment accretion around } \\
\text { the plants forms submerged shelves which protect the bank toe (Gurnell et } \\
\text { al., 2006, 2013), and also around emergent and submerged plants in mid- } \\
\text { channel locations (Cotton et al., 2006), where sediment accretion induces } \\
\text { bar development (Gradzinski et al., 2003). }\end{array}$ \\
\hline $\begin{array}{l}\text { Feature stage (ii): } \\
\text { Emergent bars / } \\
\text { shelves / berms }\end{array}$ & $\begin{array}{l}\text { Different names have been given to similar features that develop to the low } \\
\text { flow water surface level, and usually have a sharp break of slope between } \\
\text { their vegetated surface and edges. They may occupy mid-channel } \\
\text { locations, but most commonly occupy channel margins at the transition } \\
\text { between zones } 1 \text { and } 2 \text {, where the sharp break of slope between the } \\
\text { feature surface and sides reflects interaction between stabilising and } \\
\text { reinforcing vegetation and erosion by fluvial processes at the feature edges. } \\
\text { This morphology and the finer sediments from which these features are } \\
\text { constructed, distinguishes these vegetation-driven features, from the more } \\
\text { rounded side and mid-channel submerged bars and shelves created at } \\
\text { stage (i). Because of their emergent surface, emergent shelves or berms do } \\
\text { not support truly aquatic species, but instead are colonised by transitional } \\
\text { and wetland species. }\end{array}$ \\
\hline $\begin{array}{l}\text { Feature stage (iii): } \\
\text { Vegetated } \\
\text { benches and } \\
\text { islands }\end{array}$ & $\begin{array}{l}\text { These have densely vegetated surfaces that lie above the low flow water } \\
\text { level and approach the level of the floodplain within zone } 2 \text { and } 3 \text {. They } \\
\text { have a similar elevation range to benches that are formed in association } \\
\text { with wood jams. Although their formation is initiated by aquatic and wetland } \\
\text { plants along small, low-gradient rivers, riparian trees are usually also } \\
\text { involved on larger rivers. At the bench stage, some more terrestrial species } \\
\text { may start to appear within the vegetation, depending indundation duration } \\
\text { and frequency of the feature. Benches develop preferentially but not } \\
\text { exclusively on the inner banks of bends at point and counterpoint locations } \\
\text { whereas islands are mid-channel features that develop from vegetated bars. }\end{array}$ \\
\hline $\begin{array}{l}\text { Floodplain level: } \\
\text { Emergent and } \\
\text { wetland plant } \\
\text { induced levées. }\end{array}$ & $\begin{array}{l}\text { In some low-energy river systems bordered by waterlogged floodplains, the } \\
\text { above feature stages may eventually lead to significant island development } \\
\text { within an anastomosing channel pattern. Plant-fluvial process interactions } \\
\text { across the island surfaces within zone } 3 \text { may result in fine sediment } \\
\text { particles being filtered out of the flow leading to the development of low } \\
\text { levées around island and inter-anabranch floodplain edges. }\end{array}$ \\
\hline
\end{tabular}


Table 5 Characteristics of upper, middle or lower reaches of three example rivers drawn from three different biogeographical regions of Europe.

\begin{tabular}{|c|c|c|c|}
\hline & $\begin{array}{l}\text { Tagliamento } \\
\text { middle reaches }\end{array}$ & $\begin{array}{c}\text { Guadalupejo } \\
\text { middle to lower reaches }\end{array}$ & $\begin{array}{c}\text { Narew } \\
\text { upper reaches }\end{array}$ \\
\hline Biogeographic region ${ }^{1}$ & Alpine & $\begin{array}{l}\text { Mediterranean West } \\
\text { Iberian }\end{array}$ & Central European \\
\hline Biogeographic subregion ${ }^{1}$ & Eastern Alpine & Luso-Extremadurense & Hemiboreal Baltic \\
\hline Mean annual rainfall (mm) & 2000 & 650 & 580 \\
\hline $\begin{array}{l}\text { Mean daily air temperature } \\
\left({ }^{\circ} \mathrm{C}\right)\end{array}$ & 12 & 20 & 7 \\
\hline $\begin{array}{l}\text { Mean daily air temperature } \\
\text { coolest, warmest month }\left({ }^{\circ} \mathrm{C}\right)\end{array}$ & 2,22 & 6,35 & $-2,18$ \\
\hline Flow Regime ${ }^{2}$ & Perennial Flashy & Intermittent Flashy & Snow + rain \\
\hline River Types ${ }^{3}$ & $\begin{array}{l}\text { High energy anabranching } \\
\text { and braiding }\end{array}$ & $\begin{array}{l}\text { Medium energy, } \\
\text { sinuous to wandering }\end{array}$ & $\begin{array}{l}\text { Low energy, } \\
\text { anabranching } \\
\text { (anastomosing) }\end{array}$ \\
\hline Bed material & Cobble - Gravel - Sand & Cobble - Gravel & Sand \\
\hline River Channel Slope & 0.0029 & 0.0037 & 0.0002 \\
\hline Confinement & Partly confined & Partly confined & Unconfined \\
\hline $\begin{array}{l}\text { Groundwater-surface water } \\
\text { interactions }\end{array}$ & $\begin{array}{c}\text { Strong interaction } \\
\text { (downwelling and } \\
\text { upwelling) through the river } \\
\text { bed, between surface } \\
\text { water and groundwater } \\
\text { from a deep alluvial } \\
\text { aquifer. }\end{array}$ & $\begin{array}{l}\text { Strong interaction } \\
\text { (downwelling and } \\
\text { upwelling) through the river } \\
\text { bed, between surface } \\
\text { water and alluvial } \\
\text { groundwater, and also } \\
\text { contribution to alluvial } \\
\text { groundwater from hillslope } \\
\text { runoff. }\end{array}$ & $\begin{array}{l}\text { Perennially high (near- } \\
\text { surface) water table in } \\
\text { the floodplain. }\end{array}$ \\
\hline $\begin{array}{l}\text { Dominant, physical ecosystem } \\
\text { engineers, riparian tree } \\
\text { species }\end{array}$ & $\begin{array}{l}\text { Populus nigra with Salix } \\
\text { eleagnos and Alnus } \\
\text { incana. }\end{array}$ & Flueggea tinctorea. & $\begin{array}{l}\text { Trees are confined to the } \\
\text { outer areas of the } \\
\text { floodplain and are not } \\
\text { performing significant } \\
\text { ecosystem engineering. }\end{array}$ \\
\hline $\begin{array}{l}\text { Dominant, physical ecosystem } \\
\text { engineers, wetland and } \\
\text { aquatic macrophyte species }\end{array}$ & $\begin{array}{l}\text { Occasional macrophyte } \\
\text { stands found in small side } \\
\text { channels, but in general } \\
\text { stream power is too high } \\
\text { for macrophytes to perform } \\
\text { any significant physical } \\
\text { ecosystem engineering } \\
\text { role. }\end{array}$ & $\begin{array}{l}\text { The intermittent flow } \\
\text { regime does not support } \\
\text { aquatic macrophytes, and } \\
\text { so they are only present in } \\
\text { small areas that are } \\
\text { subject to local } \\
\text { groundwater upwelling. }\end{array}$ & $\begin{array}{c}\text { In anabranches, } \\
\text { Phragmites australis, } \\
\text { Sagittaria sagittifolia and } \\
\text { Sparganium erectum trap } \\
\text { and stabilize sediments, } \\
\text { leading to bar and bench } \\
\text { development. On the } \\
\text { floodplain, tussock- } \\
\text { forming species (e.g. } \\
\text { Carex elata) influence } \\
\text { microtopogarphy and } \\
\text { funnel flood water. }\end{array}$ \\
\hline
\end{tabular}

${ }^{1}$ Rivas-Martinez et al. (2004); ${ }^{2}$ Bussettini et al. (2011); ${ }^{3}$ Rinaldi et al. (2015) 


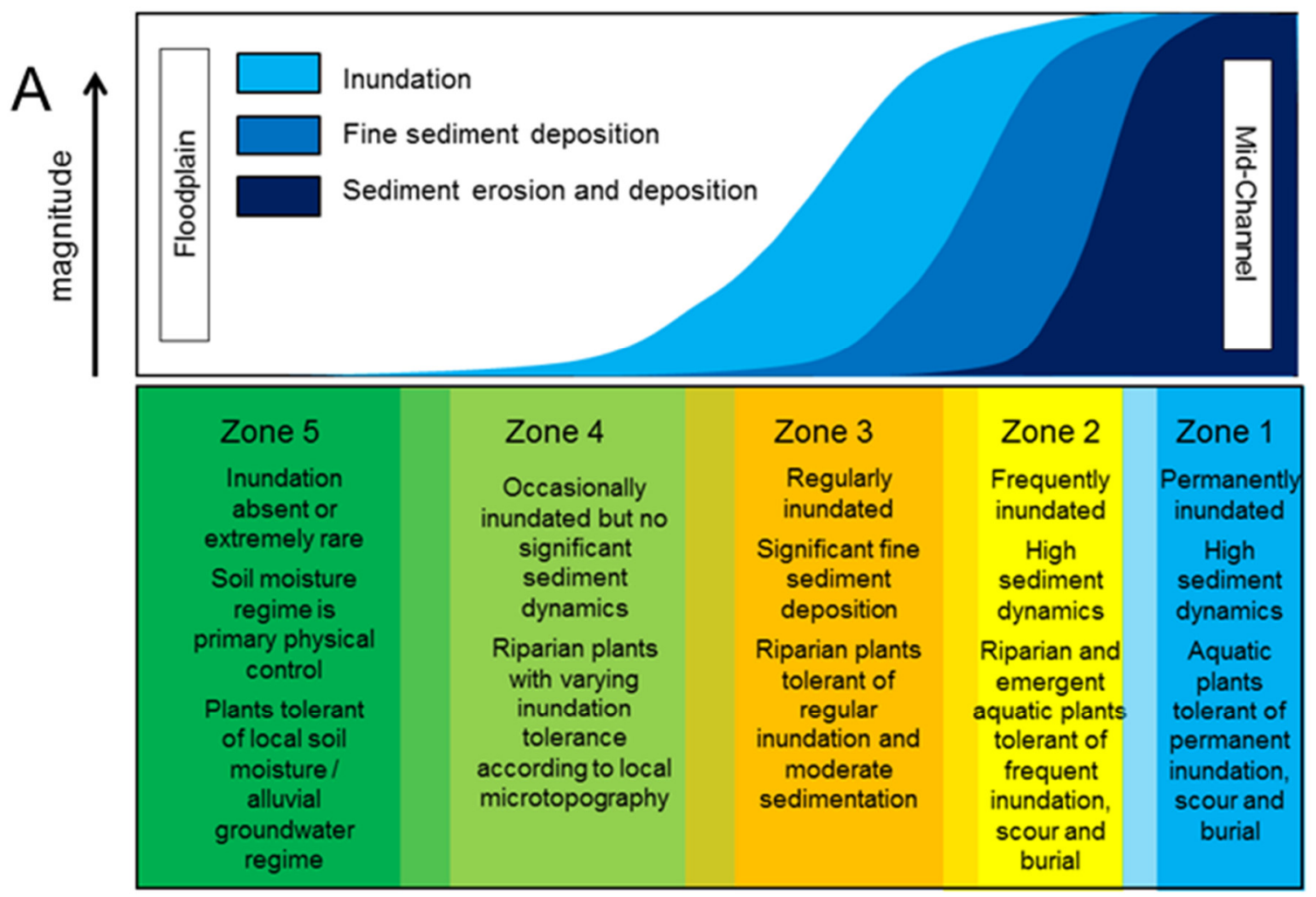

B

Zone 1 Perenially inundated

Zone 2 Fluvial disturbance dominated (coarse sediment erosion \& deposition)

Zone 3 Fluvial disturbance dominated (finer sediment deposition)

Zone 4 Inundation dominated

Zone 5 Soil moisture regime dominated Hills

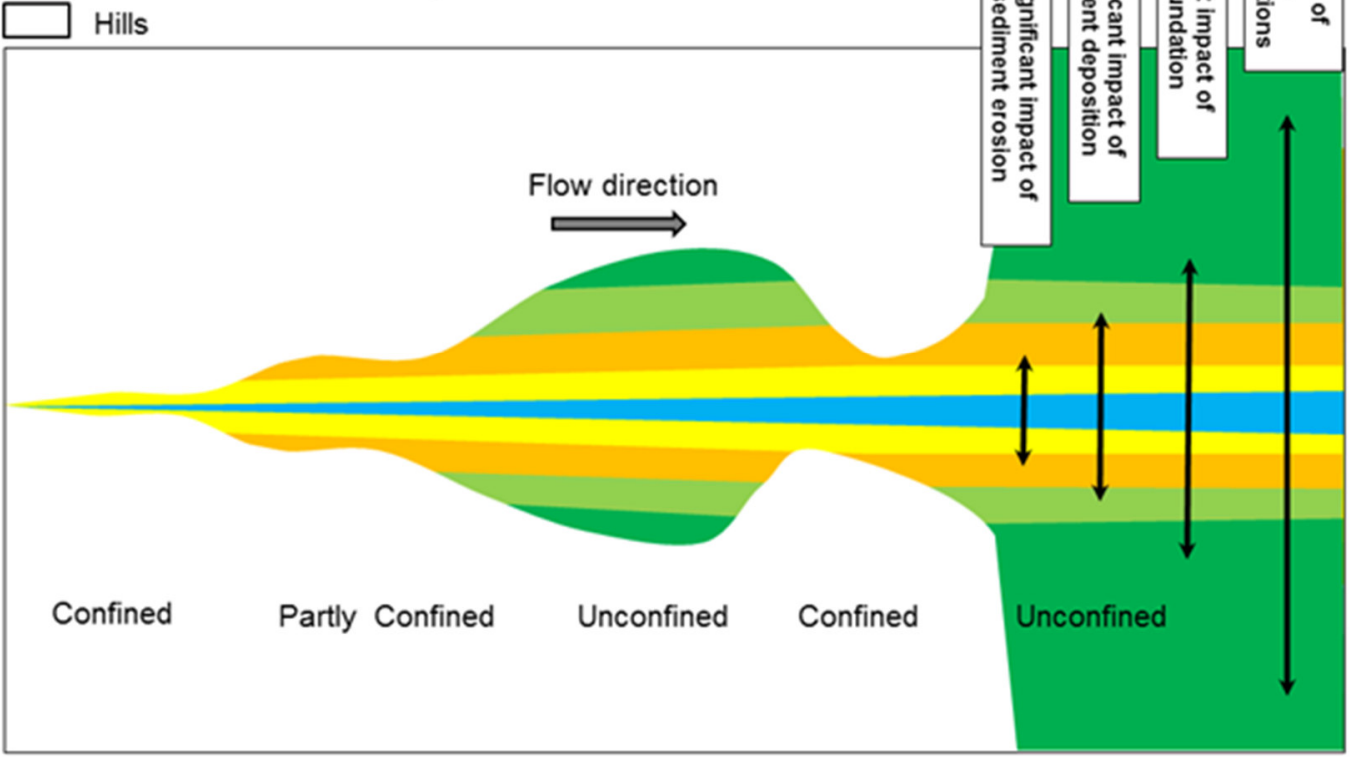

Figure 1:

A. Hydrogeomorphological characteristics of the five zones of a river corridor in relation to the magnitude of inundation, fine sediment deposition, or sediment erosion and deposition.

B. Schematic longitudinal and lateral variations in the dominant hydrological and fluvial processes that influence vegetation composition, growth performance and turnover along a river located within a valley of varying confinement. 


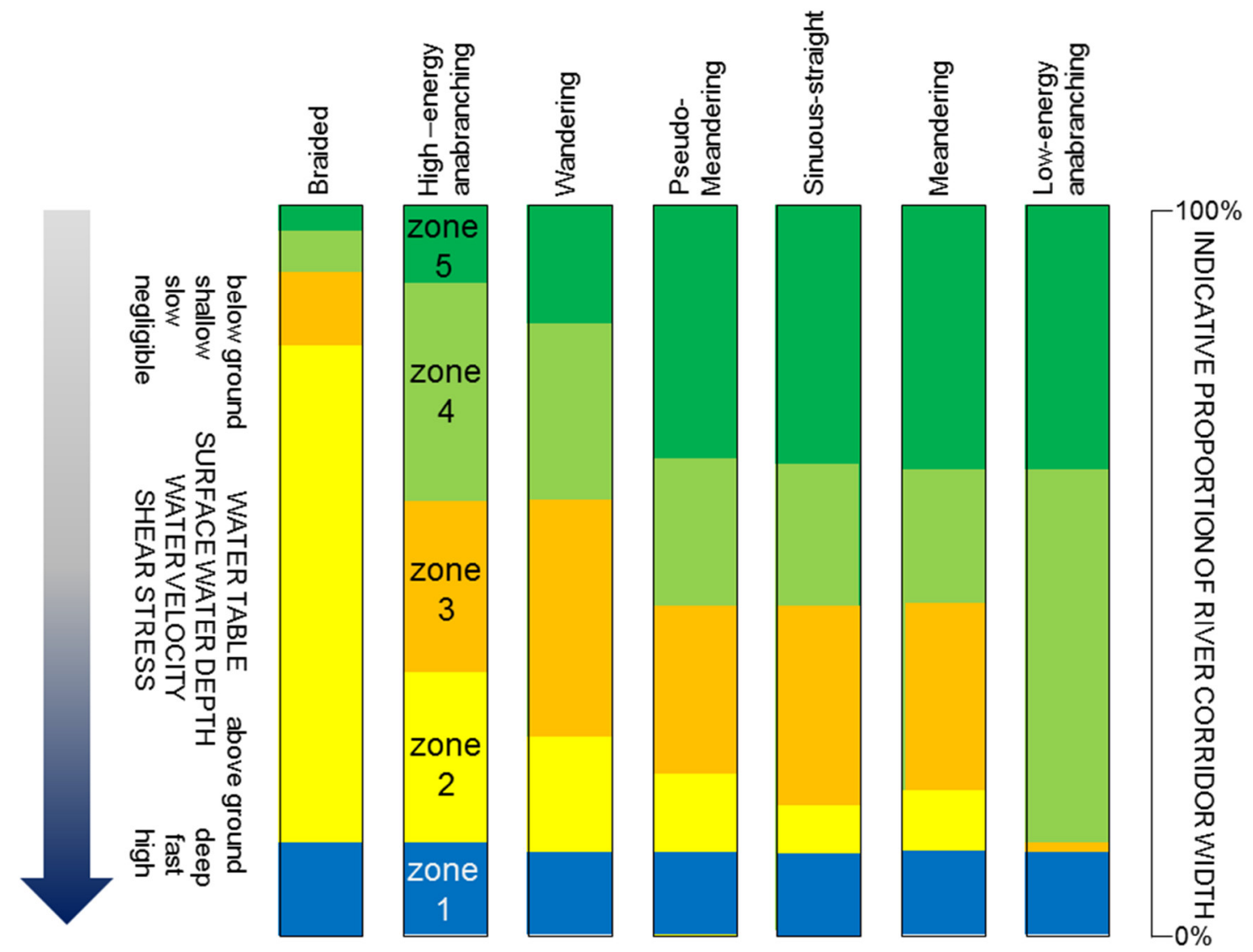

Figure 2 Indicative relative proportions of the five river corridor lateral zones where vegetation might be dominated by the different hydrogeomorphological processes in unconfined reaches subject to different river planform types, and the hydrogeomorphological process gradients (left axis) that drive the lateral zonal mosaic. Note that the process gradients vary in their extent along the left vertical axis according to the river planform being considered. 


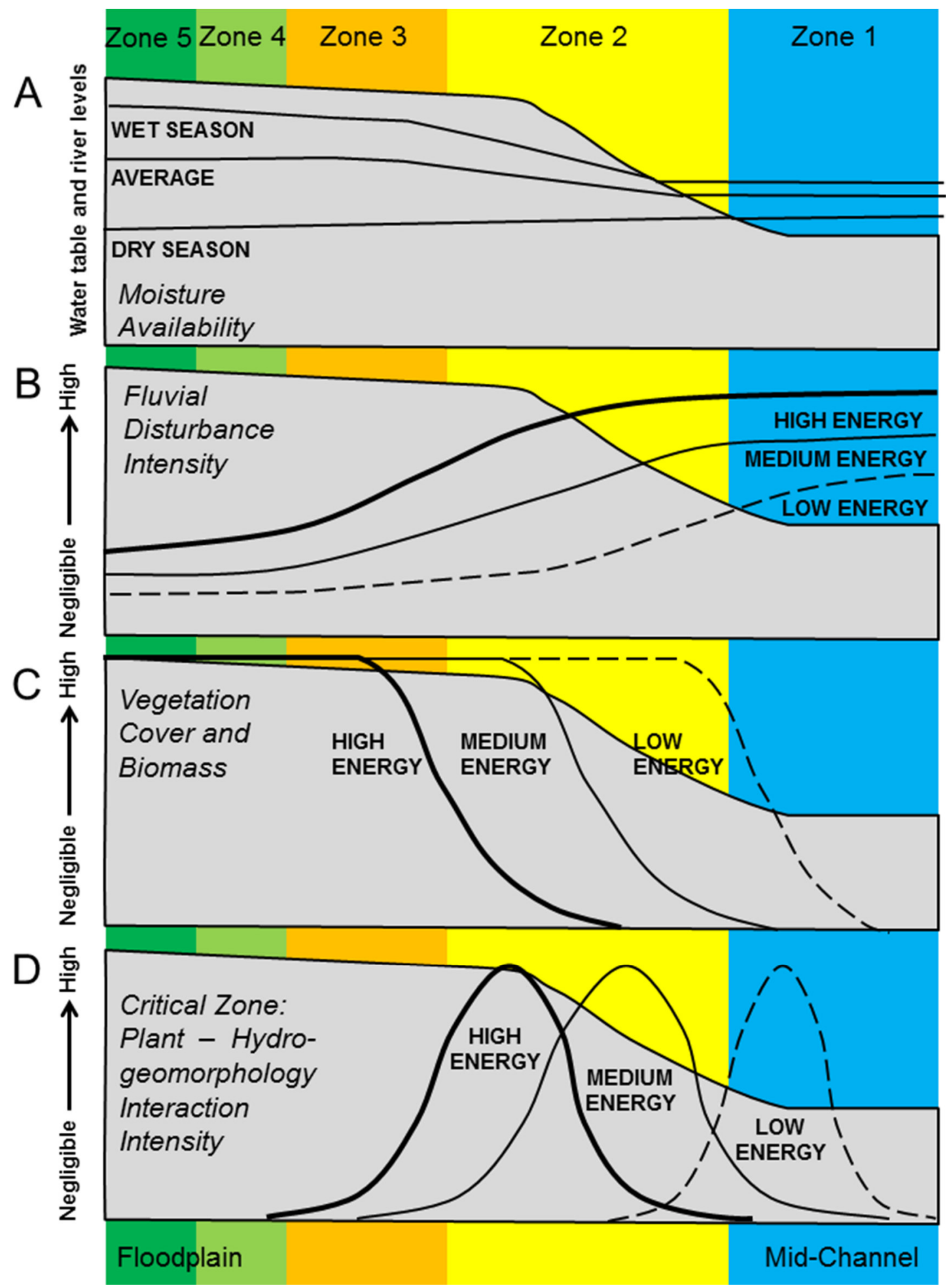

Figure 3. Schematic diagram for a river in a moist environment (e.g. the example reach of the high energy Tagliamento River) from the centre of the river channel (right) to the outer limit of the floodplain / river corridor (left), showing typical lateral distributions of water table and river levels during the dry season, wet season and annually $(A)$; and broad lateral distributions of fluvial disturbance intensity (B); vegetation cover and biomass (C); and the extent and intensity of the critical zone of plant - fluvial process interactions (D) in high, medium and low energy river contexts. Note that the 5 zones represent the situation for the medium energy case. 

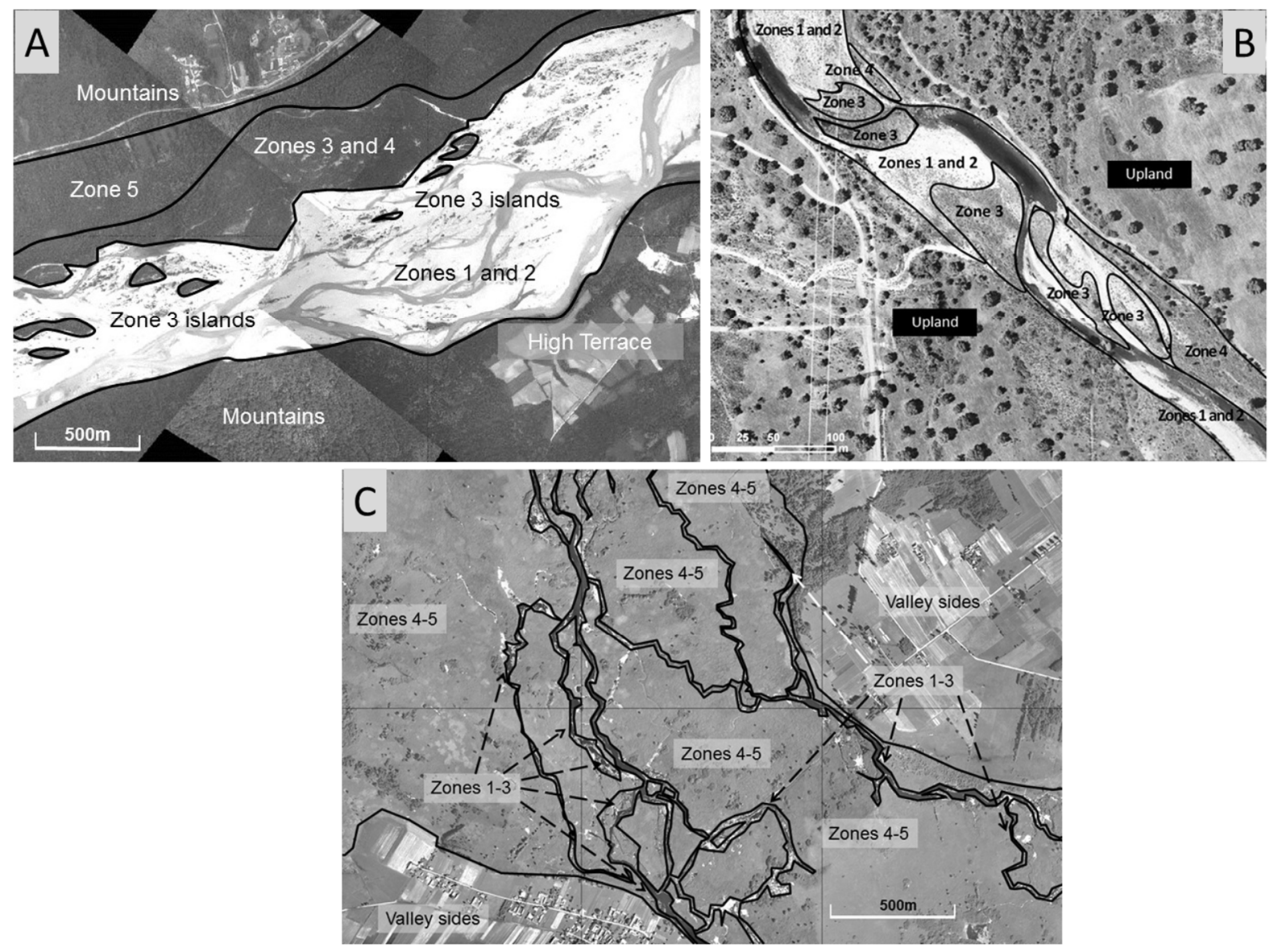

Figure 4. The distribution of aggregate zones across the river corridors of example reaches of three near naturally functioning European rivers.
A. Tagliamento River, Italy (air photograph courtesy of the UK Natural Environment Research Council).
B. Guadalupejo River, Spain (air photograph courtesy of the National Geographic Institute of Spain).
C. Narew River, Poland. 


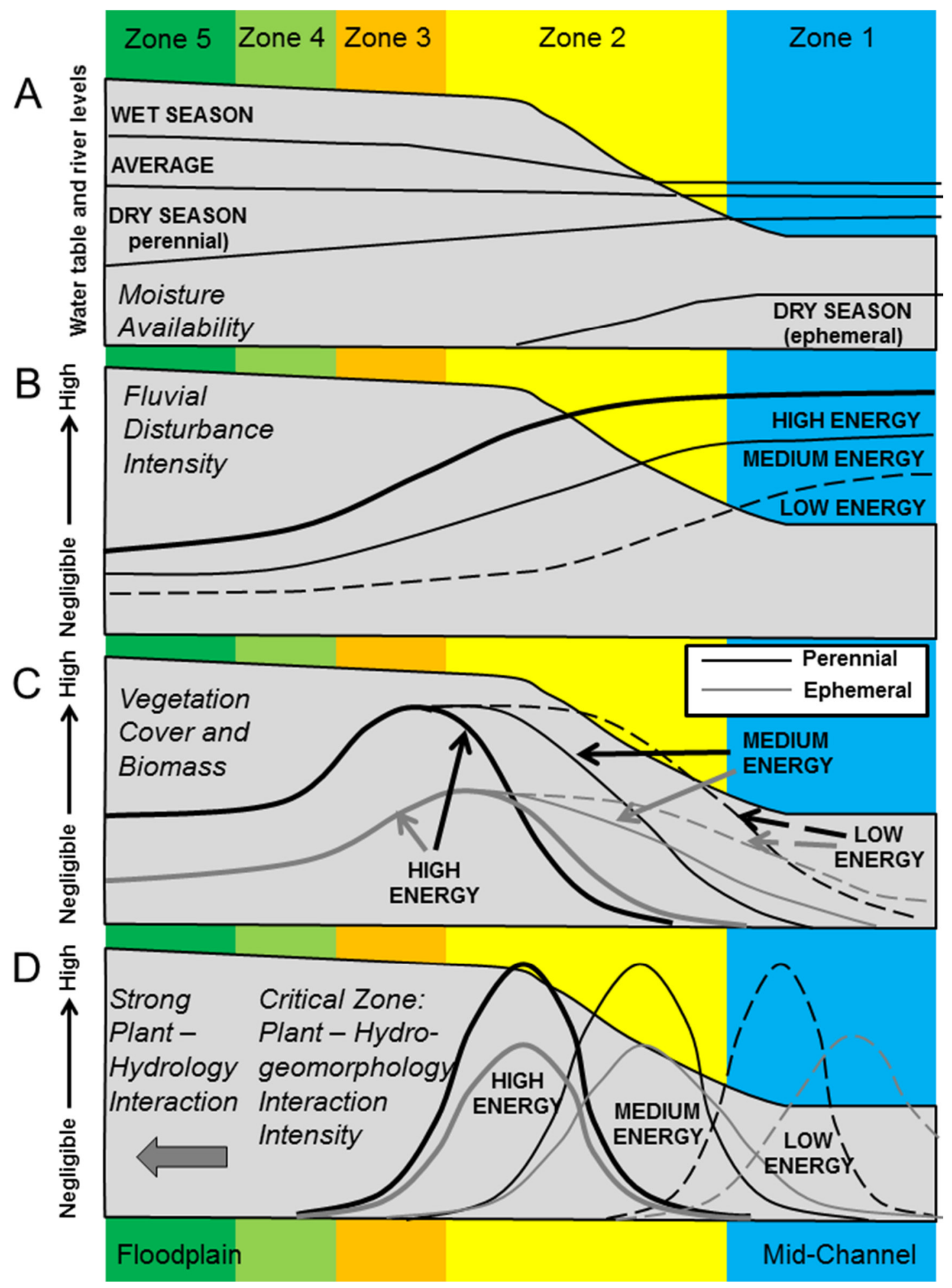

Figure 5. Schematic diagram for rivers in a dry environment (e.g. the example reach of the ephemeral Guadalupejo River) from the centre of the river channel (right) to the outer limit of the floodplain / river corridor (left), showing typical lateral distributions of water table and river levels during the dry season, wet season and annually (A); and broad lateral distributions of fluvial disturbance intensity (B); vegetation cover and biomass $(C)$; the extent and intensity of the critical zone of plant hydrogeomorphological process interactions and the zone of strong plant - hydrology interactions (D). Patterns are shown for high, medium and low energy, perennial and ephemeral rivers but the 5 zones represent the situation for medium energy rivers. 

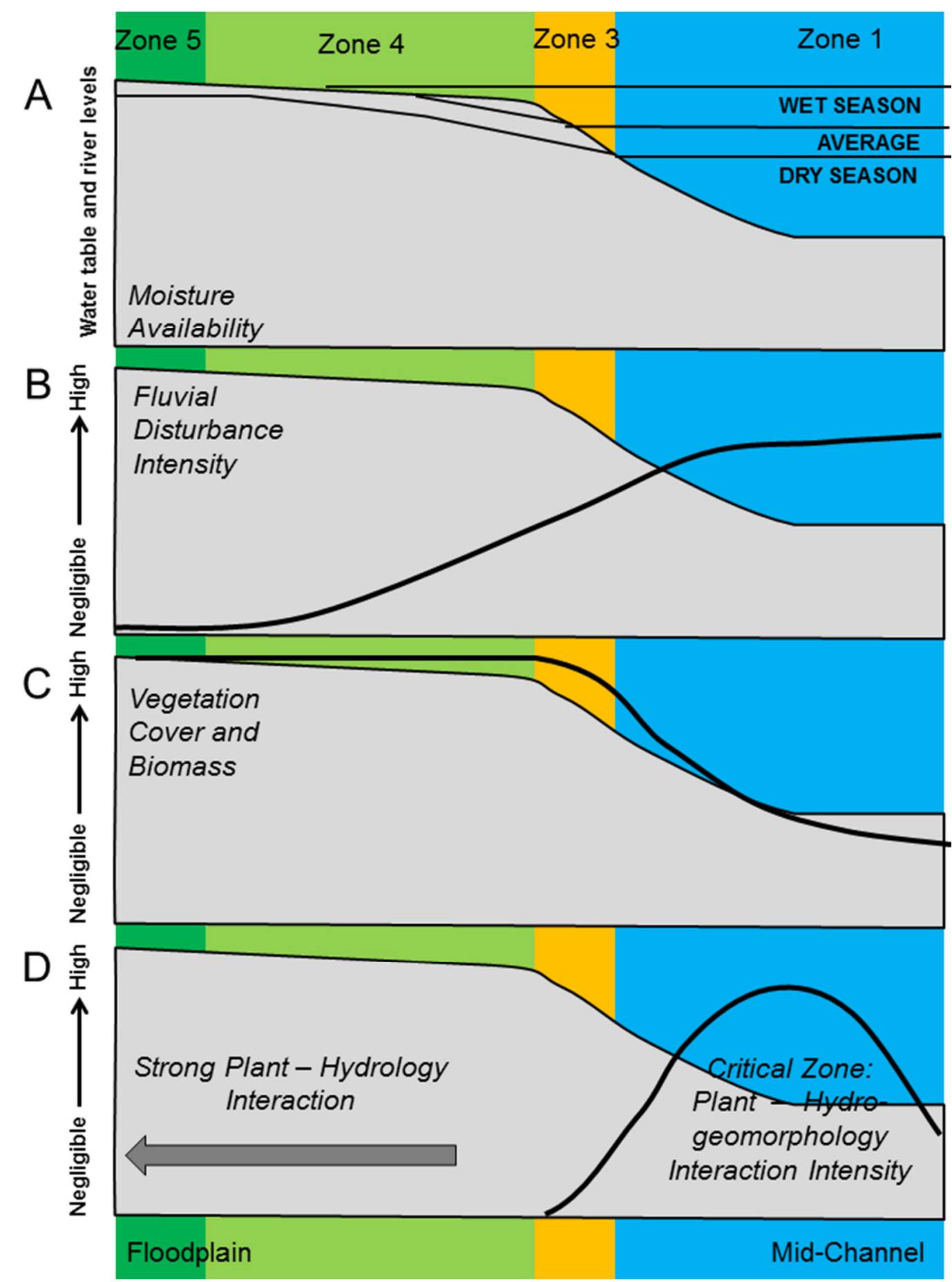

Figure 6. Schematic diagram for an extremely low energy river in a moist environment (e.g. the example reach of the Narew River) from the centre of the river channel (right) to the outer limit of the floodplain / river corridor (left), showing typical lateral distributions of water table and river levels during the dry season, wet season and annually (A); and broad lateral distributions of fluvial disturbance intensity (B); vegetation cover and biomass (C); the extent and intensity of the critical zone of plant hydrogeomorphological process interactions, mainly in zone 1 and the zone of strong plant - hydrology interactions in zones 4 and 5 (D). 